\title{
STUDI TEKSTUAL MODEL-MODEL PERTANYAAN ALLAH DALAM KEJADIAN 3:8-13
}

\author{
Oleh : Pdt. Donna Crosnoy Sinaga, M.Th \\ Pembantu Ketua II Bidang Keuangan
}

\begin{abstract}
ABSTRAK
Studi tekstual merupakan salah satu bentuk kajian yang penting dilakukan untuk memperdalam pemahaman makna/ kebenaran/ realita suatu teks. Dalam hal ini ialah terkait dengan berbagai bentuk (model) pertanyaan-pertanyaan Allah kepada Adam setelah jatuh ke dalam dosa. Tidak dapat dipungkiri bahwa secara literal memang sulit memahami jika Allah bertanya terkait dengan informasi yang ingin dibutuhkanNya. Namun realitas teks menyajikannya dalam Kejadian 3:8-13. Itulah sebabnya pendekatan tekstual salah satu studi yang dilakukan untuk memahami kebenaran yang dimaksud.

Adapun metode yang dilakukan dalam penelitian ini ialah dengan kajian induktif tekstual dan eksegetikal. Induktif tekstual dilakukan dengan studi kata terhadap kata-kata tertentu yang representasi terhadap problema teks. Kajian eksegetikal dilakukan dengan pendekatan gramatikal dan leksikal. Dengan pendekatan studi ini ditemukan fakta teks bahwa bahwa pertanyaan yang diajukan Allah lebih bersifat refleksional daripada informatif, yang umumnya dapat dipahami sebagai pertanyaan retoris.
\end{abstract}

\section{Kata Kunci : Literal, Gramatikal, Retoris, Mendengarkan, Bersembunyi, Dosa}


Pemahaman terhadap model-model pertanyaan Allah dan problema di dalamnya tidak hanya membutuhkan kajian teologis yang komprehensip namun juga kajian tekstual agar dapat memaknai nilai dan kebenaran-kebenaran teks. Kita harus menyadari pentingnya peranan teks dalam menyarikan dan membangun prinsip/ argumentasi teologis. Kepentingan studi teks ini ialah menolong untuk mendapatkan perspektif dan kedalaman dalam pemahamannya terhadap kata yang dipelajari, dan penghargaan yang lebih besar terhadap kemungkinankemungkinan dan nuansa-nuansanya. ${ }^{1}$ Adapun tujuan dari Studi Teks Kejadian 3:8-13 ialah untuk mempelajari kata-kata/ frasa-frasa tertentu yang dapat memberikan pemahaman penting terhadap teks yang sedang dibahas. Tujuan kedua juga masih dalam penelitian teks namun lebih terfokus pada kalimat-kalimat tanya yang digunakan penulis ketika Allah bertanya. Sebab suatu pertanyaan tidak hanya dinilai maksudnya dari isi pertanyaan, namun juga dipengaruhi gaya bertanya ataupun kalimat tanya yang digunakan. Kajian studi teks ini akan membahas perikop kitab Kejadian 3:8-13 secara representatif oleh kata-kata tertentu, yang dapat memberikan kontribusi (implisit/ eksplisit) terhadap pemahaman model-model pertanyaan Allah.

\section{A. STUDI KATA "MENDENGARKAN" (um^v* $\left.\left[\mathrm{v}^{*} \mathrm{~m} \wedge \mathrm{u}\right]\right)$}

Konteks yang menjadi pembahasan dalam disini adalah era baru dalam kehidupan manusia. Manusia sudah tidak hidup lagi dalam persekutuan dan kebersamaan dengan Allah seperti yang sedianya direncanakan Allah. Salah satu implementasi dari era baru itu adalah bentuk pendengaran mereka akan kehadiran Allah. Kehadiran Allah yang didengar oleh telinga mereka melahirkan reaksi yang sebelumnya tidak pernah terjadi. Adanya fenomena yang baru ini, juga diyakini oleh Gordon J. Wenham, yakni ketika ia berkata:

"Karena itu kelihatan sepertinya bahwa hal itu bukanlah hal yang tidak biasa baginya mendengar Allah berjalan di taman pada waktu hari sejuk. Mungkin percakapan/ komunikasi

\footnotetext{
${ }^{1}$ Stanley D. Toussaint, Metode Studi Kata dalam Perjanjian Baru, pen., Ari Upu Telo. (Artikel ini diberikan dalam perkuliahan Metode Mempelajari Alkitab Lanjutan, thn. 2004).
} 
antara Allah dengan ciptaan-Nya adalah adalah hal yang biasa dalam kesehariannya."2

Jalan Allah ini tidak dapat dimaknai sama seperti jalan Allah sebelumnya, atau bentuk jalan Allah ini bukanlah jalan yang biasanya, tetapi suatu reaksi Adam dengan isterinya. Mereka "sembunyi... diantara pohon-pohon dalam taman." Argumen ini merupakan kerangka berpikir yang sama ketika mengamati kondisi Adam dan Hawa ketika dalam keadaan telanjang. Pada Kejadian 2:25 ketelanjangan itu adalah kondisi yang biasa bagi mereka dan mereka tidak malu. Akan tetapi, pada Kejadian 3:7,10 kondisi/ keadaan yang sama melahirkan reaksi yang berbeda. Mereka menyemat daun pohon ara dan membuat cawat, selanjutnya mereka bersembunyi dari Allah karena takut dan malu. Bentuk perubahan inilah yang diyakini oleh penulis juga merupakan perubahan yang sama pada waktu mereka mendengar langkah Allah. ${ }^{3}$ Adalah mustahil kalau langkah Allah yang mereka dengar pada ayat 8 , adalah langkah Allah yang pertama.

Sebelum kejatuhan Adam dan Hawa tentu Tuhan Allah sudah sangat sering mengunjungi taman Eden dan berkomunikasi dengan mereka (bdk Kej. 2:15-17). Akan tetapi, kali ini bunyi langkah Tuhan yang sedang berjalan-jalan dalam taman itu justru menimbulkan rasa takut bukannya pengharapan yang penuh sukacita. Dalam kepentingannya terhadap pemahanan konteks baru ini, maka penulis memilih untuk melakukan studi teks terhadap kata $u m^{\wedge} v^{*}\left(v^{*} m \wedge u\right)$.

\section{B. INTERPRETASI GRAMATIKAL}

Penafsiran gramatikal merupakan bentuk penafsiran dengan menekankan pada tata bahasa kata tertentu. Hal ini sangat penting, sebab satu kata dapat memiliki makna dan fungsi yang berbeda dan hal itu sangat dipengaruhi oleh tata bahasa.

Kata 'mendengarkan' dalam Kejadian 3 digunakan sebanyak 3 kali, 2 di antaranya terdapat pada perikop pembahasan ini. Kata 'mendengar' $\left(\mathrm{V}^{*} \mathrm{~m} \wedge \mathrm{U}\right)$ pada ayat 8 merupakan kata yang pertama kali digunakan dalam Alkitab. Akan tetapi aktivitas pendengaran bukanlah

${ }^{2}$ Gordon J. Wenham, Word Biblical Commentary Genesis 1-15, peny., John D. W. Watts (Waco: Word Books Publisher, 1987), hlm. 1:76.

${ }^{3}$ Ibid. 
yang pertama kalinya pada bagian ini. Bentuk hubungan dan komunikasi antara Allah dan Adam, serta Adam dan Hawa menunjukkan bahwa aktivitas pendengaran telah pernah terjadi sebelumnya. Salah satu contoh yang jelas ialah ketika TUHAN Allah memberikan perintah kepada Adam mengenai buah yang boleh dan tidak boleh dimakan (Kej. 2:16). Penulis yakin bahwa perintah yang diberikan oleh Allah itu didengar oleh Adam, hal ini jelas karena, dakwaan yang diberikan Allah kepada Adam ialah atas apa yang telah didengarnya tetapi tidak diindahkannya (Kej. 3:17). Ketika Allah memberikan konsekuensi atas tindakannya, Adam sama sekali tidak membantah, dan ini merupakan bukti bahwa ia mendengar dan mengetahui perintah Allah itu.

$$
\text { Wum }=\mathrm{v}=Y ! \mathrm{W} \sim \quad(\mathrm{W} \sim \mathrm{Y} ! \mathrm{vm}=\mathrm{UW}) \text { berasal dari kata dasar } u \mathrm{~m}^{\wedge} \mathrm{v}^{*}
$$

$\left(\mathrm{V}^{*} \mathrm{~m} \wedge \mathrm{U}\right)$ yang artinya mendengarkan, parsingnya ialah waw konsekutif - Qal Imperfek ${ }^{4}-3$, m, j, yang kemudian diterjemahkan mereka telah mendengar."5 Kata kerja ini memiliki pangkal Qal. Pangkal Qal memiliki dua bentuk dan fungsi yaitu statif dan fientif. Dalam fungsinya sebagai statif menyatakan atau mengekspresikan suatu keadaan atau kondisi, dan dalam fungsinya sebagai fientif yaitu menyatakan atau mengekspresikan suatu tindakan atau kegiatan. ${ }^{6}$ Dalam konteks ini pangkal Qal memiliki bentuk dan fungsi fientif. Adapun tindakan yang dimaksud dalam konteks ini ialah mendengar Allah berjalan di taman. Stem kata kerja $W \sim Y ! \vee m=\cup W$ adalah

${ }^{4}$ Dalam bahasa Ibrani, aspek imperfek mengandung dua makna yang utama: Pertama, untuk menunjukkan tindakan yang belum lengkap atau selesai dalam waktu lampau atau kini; Kedua, untuk menunjukkan suatu situasi yang tergantung pada pembicara, subyek, atau situasi yang lain. Adapun fungsi aspek imperfek ialah menunjukkan tindakan yang belum lengkap atau selesai, menunjukkan tindakan yang berulang-ulang pada suatu waktu, tindakan yang biasanya dilakukan pada waktu tertentu, mengungkapkan kemampuan (potential), mengungkapkan izin (permissive), mengekspresikan suatu keinginan, menunjukkan kewajiban, mengungkapkan suatu perintah yang keras, digunakan dalam persyaratan (conditional), dan terakhir digunakan sesudah partikel yang menunjukkan maksud. Diambil dari: Carl Reed dan Johny Y. Sedi, Diktat Kuliah: Bahasa Ibrani Jilid III Grammar dan Sintaks, sem., V, 2004.

${ }^{5}$ Bible Work for Windows Copyright (c) 2003 Bible Works, LLC Version 6.0.005y WTM Morphology + Whittaker's Revised BDB Lexicon entry (pg.1033,251). [CD ROOM].

${ }^{6}$ Carl Reed dan Johny Y. Sedi, Diktat Kuliah: Bahasa Ibrani Jilid III Grammar dan Sintaks, sem., V, 2004. 
imperfek, namun dalam fungsinya ia diterjemahkan perfek. Pergantian ini terjadi karena kata $W \sim Y ! \vee m=\cup W$ diikuti oleh waw konsekutif. Waw konsekutif digunakan dalam rangka penukaran fungsi bentuk kata kerja. ${ }^{7}$ Waw konsekutif dengan perfek mengandung arti yang sama dengan kala (aspek) imperfek dari kata kerja yang pertama, demikian sebaliknya, waw konsekutif imperfek mengandung arti yang sama dengan kala (aspek) perfek dari kata kerja pertama dalam klausa. ${ }^{8}$ Dalam konteks ini waw konsekutif melekat pada imperfek sehingga mengandung arti perfek dan diterjemahkan "mereka telah mendengar."

Aspek perfek atau kompletif adalah aspek yang menggambarkan perbuatan lengkap. Perbuatan ini bisa suatu peristiwa yang telah terjadi (waktu lampau), yang sedang terjadi tetapi dianggap sudah lengkap, atau peristiwa lengkap yang terjadi pada waktu yang akan datang. Adapun fungsi atau penggunaan aspek perfek ialah untuk menunjukkan arti statif, yaitu mengekspresikan suatu keadaan atau kondisi, digunakan untuk mengekspresikan tindakan yang telah lengkap atau selesai dalam realita atau dalam pandangan si pembicara, digunakan untuk experience (pengalaman) ketika kata kerja fientif menunjukkan suatu keadaan atau pikiran, digunakan untuk menunjukkan suatu tindakan yang sudah lengkap pada saat dibuat, digunakan untuk menunjukkan kepastian, digunakan dalam persyaratan yang tidak riil di masa lampau. ${ }^{9}$ Dalam konteks ini aspek perfek lebih tepat digunakan untuk menyatakan experience (pengalaman) karena kata kerja fientif menunjukkan suatu keadaan ketika Adam dan Hawa mendengar kehadiran Allah, yaitu mereka bersembunyi.

Kehadiran Allah dalam peristiwa ini ialah dalam wujud teofani. Teofani ialah penampakan ilahi yang dapat dilihat oleh mata jasmaniah. ${ }^{10}$ Salah satu contoh kehadiran Allah dalam wujud teofani ialah pada peristiwa Yakub bergulat dengan seorang laki-laki. Pada awalnya Yakub tidak mengenal siapa lawan ia bergulat, tetapi pada akhirnya dia berkata "Aku telah melihat Allah berhadapan muka" (Kej. 32:30). Tentulah yang dilihat oleh Yakub ialah Allah dalam wujud teofani. Sebab Allah berkata kepada manusia bahwa tidak ada manusia yang dapat melihat-Nya dan tetap hidup (Kel. 33:20). Demikian juga

${ }^{7}$ Samgar Setia Budi, Diktat Kuliah: Bahasa Ibrani, sem., V, 2003.

${ }^{8}$ Reed dan Sedi, Diktat Kuliah.

${ }^{9}$ Reed dan Sedi, Diktat Kuliah, hlm. 49-52.

${ }^{10}$ Henry C. Thiessen, Teologi Sistematika, ref., Vernon D. Doerksen (Malang: Gandum Mas, 2000), hlm. 115. 
Yohanes mengatakan bahwa "Tidak seorangpun yang pernah melihat Allah" (Yoh 1:18), selanjutnya Paulus menyebut Tuhan sebagai "Allah yang tidak kelihatan" (Kol. 1:15), serta menyatakan bahwa tidak ada orang yang telah melihat Allah atau dapat melihat Allah (I Tim 6:16). ${ }^{11}$

Pada umumnya kehadiran Allah dalam wujud teofani ialah dalam hal-hal tertentu atau membawa misi khusus. Beberapa di antaranya ialah pada peristiwa kelahiran Ismael (Kej. 16:7-16), peneguhan janji mengenai keturunan kepada Abraham, pengutusan Musa (Kel. 3:2-5), dan berbagai peristiwa penting lainnya. Dalam kaitannya dengan teofani Allah pada konteks ini ialah kondisi Adam dan Hawa yang telah berdosa, tidak memungkinkan mereka untuk bertemu langsung dengan Allah, hubungan/ komunikasi yang telah rusak dengan Allah serta terbukanya pintu kematian kekal bagi manusia. Di tengah-tengah kondisi inilah Allah mengambil inisiatif mendatangi atau mencari Adam dan Hawa dalam wujud teofani. Penegasan yang lebih ditambahkan oleh John J. Davis yang mengatakan bahwa penggunaan

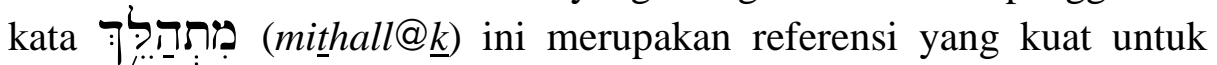
memahami kehadiran Allah dalam wujud teofani. ${ }^{12}$

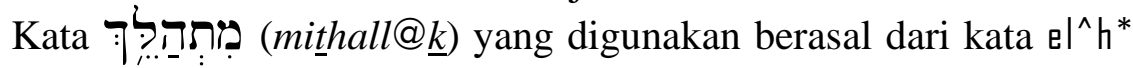
$(h ` \mid \wedge$ :) yang artinya berjalan. Kata ini merupakan kata yang umum digunakan dalam Perjanjian Lama dalam bentuk metapora mengenai kehidupan. Kata ini digunakan lebih dari 1500 kali, baik secara figuratif maupun literal. Penggunaan kata mithall@ $\underline{k}$ dengan stem hitpael adalah nuansa yang khusus dalam penggunaannya, ${ }^{13}$ yang menggambarkan tindakan berjalan atau melangkah. Penggunaan pertama kata $h ` \wedge$ : dengan arti ini ialah pada peristiwa Allah berjalan dalam taman (Kej. 3:8). Pada persitiwa Henokh berjalan dengan Allah, penggunaan bentuk hitpael juga menggambarkan hubungan/ kedekatan dengan Allah (Kej. 5:22, 24). Sejarah penggunaan hitpael adalah sebagai kode untuk kekuasaan yang dapat diilustrasikan pada contoh Abraham (Kej. 13:17) dan pengutusan Yosua sebagai salah satu pengintai. Yosua memerintahkan kepada para pemimpin suku Israel

\footnotetext{
${ }^{11}$ Thiessen, Teologi Sistematika, hlm. 114.

${ }^{12}$ John J Davis, Eksposisi Kitab Kejadian "Suatu Telaah dalam Kitab Kejadian (Malang: Gandum Mas, 2001), hlm. 97.

${ }^{13}$ Eugene H. Merrill, "el $\left.\right|^{\wedge} \mathrm{h},{ }^{*}$ " dalam New International Dictionary of Old Testament Theology and Exegesis, peny., Willem A. VanGemeren (Carliste: Paternoster Press, 1997), hlm. 1:1034.
} 
untuk mengutus 3 orang dari tiap-tiap suku untuk menjelajahi negeri Kanaan (Yos. 18:4, 8). ${ }^{14}$ Dengan mempelajari bentuk-bentuk penggunaan hitpael maka penulis menyimpulkan bahwa konteks Allah berjalan dalam taman ialah berjalan secara literal dalam wujud teofani.

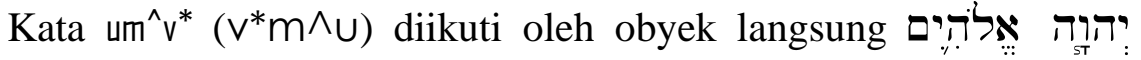
אֶת (A\#f-qol $y=h w \sim h$ 'ělōhîm) yang diterjemahkan bunyi atau suara YHWH Elohim. Frase "bunyi atau suara YHWH Elohim" mengandung makna ambigu jika ditelusuri dari sumbernya. Berikut John H. Sailhamer menguraikannya:

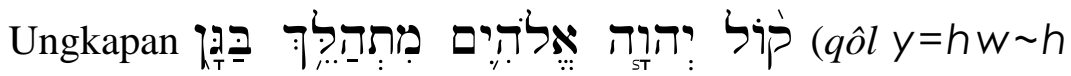
'ělohîm mithall@ @ bagān) dapat dipahami dengan dua cara, pertama dapat menunjuk pada bunyi yang diakibatkan gerak jalan TUHAN di taman (NIV), kedua dapat menunjuk pada suara TUHAN yang bergema (mithall@ $\underline{k}$ : bdk.Yer 46:22). Kata "bunyi" ( $q \hat{o} l)$ dapat menunjuk pada suara langsung dari Allah (U1. 5:25), itu dapat merujuk pada "bunyi" dari teopani, misalnya guntur (Kel. 20:18). Jawaban Adam pada ayat 10 "aku mendengar suaramu di dalam taman" (I heard Your voice in the garden ${ }^{15}$ ) menunjukkan dengan jelas bahwa bunyi yang mereka dengar bukanlah bunyi langkah Allah. Tetapi juga, ketika ayat 9 dikatakan "tetapi Allah memanggil mereka," ini menunjukkan bahwa bunyi yang mereka dengar pada ayat 8 bukanlah suara Allah, ${ }^{16}$ sebab TUHAN Allah baru mengeluarkan perkataan pada ayat 9 .

Dari uraian Sailhamer di atas terdapat permasalahan mengenai bunyi apakah yang mereka dengar. Terjemahan LAI menafsirkan bahwa bunyi yang didengar oleh Adam dan Hawa ialah bunyi langkah

\footnotetext{
${ }^{14}$ Merrill, "e $\left.\right|^{\wedge} h,{ }^{*}$, dalam New International Dictionary of Old Testament Theology and Exegesis, hlm. 1:1034.

${ }^{15}$ Terjemahan ini adalah versi New King James, penulis memilih versi ini karena menurut penulis, salah satu terjemahan yang paling dekat dengan terjemahan teks asli adalah versi ini. Versi Inggris lain yang menggunakan terjemahan yang sama pada bagian ini ialah American Standard Version (ASV), (BBE), (KJG), (LXE), (RWB), (WEB). Diambil dari Bible Work for Windows Copyright @ 2003 Bible Works, LLC Version 6.0.005y WTM.

${ }^{16}$ John H. Sailhamer, "Genesis," dalam The Expository Bible Commentary, peny., Frank E. Gaebelein (Grand Rapids: Zondervan Publishing House, 1991), hlm. 2:53.
} 
Allah (Kej. 3:8). Dalam bahasa aslinya kata "langkah" memang tidak ditemukan. Sebagian besar terjemahan Inggris tidak sesuai dengan terjemahan LAI dalam konteks ini.

Kata bunyi (sound) atau suara (voice) berasal dari kata "קi"ל $(q \circ /)$. Kata ini digunakan sebanyak 506 kali, kata ini juga ditemukan dalam bahasa Ugaritik (bunyi), dalam bahasa Akad (memanggil), bahasa Arab (berkata), bahasa Fenisia, Etiopia, dan Arab selatan dan kuno (suara). ${ }^{17}$ Arti pertama kata qol menunjukkan pada bunyi yang dihasilkan oleh kawat. Ini juga termasuk bunyi suara manusia, contohnya ialah suara permohonan bangsa Israel yang didengar oleh Tuhan (Yos. 10:14). Kata ini juga digunakan untuk menyatakan bunyi yang dihasilkan binatang. Ketika Tuhan memerintahkan Saul melalui Samuel untuk menumpas bangsa Amalek beserta segala sesuatu yang mereka miliki, Saul tidak menaati perintah Tuhan. Saul dan rakyatnya menyelamatkan Agag raja Amalek dan kambing domba dan lembulembu yang terbaik dan tambun tidak ditumpas mereka. Ketika Samuel mendatangi Saul, ia mendengar 'bunyi' kambing domba dan lembulembu (1 Sam. 1-14). Selanjutnya kata ini juga dapat digunakan dalam bentuk personifikasi (suara darah adikmu berteriak kepada-Ku dari tanah). ${ }^{18}$

Dari pemahaman kata qo/ ini sendiri sulit untuk menentukan bunyi apa yang didengarkan oleh Adam dan Hawa, karena kata itu sendiri dapat digunakan dalam kedua konteks yang sedang dibahas.

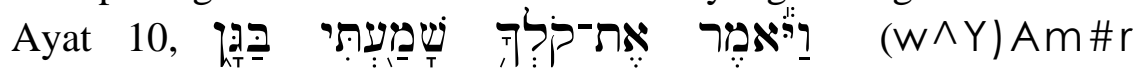
$\left.\left.A \# t^{-} \mathrm{q}\right) \mathrm{I}=I^{\prime} \mathrm{V}^{*} \mathrm{~m} \wedge \mathrm{UT} \hat{\imath} \quad \mathrm{B} \sim \mathrm{G}^{\prime} \mathrm{n}\right)$ dapat diterjemahkan "dan ia berkata aku mendengar suara-Mu dalam taman." Kata suara yang digunakan sebenarnya sangat mempengaruhi apa yang mereka dengarkan. Akan tetapi kata suara itu sendiri tidak dengan bebas dapat diterjemahkan, karena kata yang digunakan q)। juga dapat diterjemahkan bunyi dalam konteks ini. Jika yang digunakan adalah bunyi, maka jelas ini lebih menunjuk pada bunyi langkah kaki Allah. Dalam berbagai Alkitab Versi Inggris kata q)। diterjemahkan "voice" dan "sound" namun diakui bahwa sebagian besar lebih memilih kata

\footnotetext{
${ }^{17}$ Archer dan Lainnya, "voice," dalam Vine's Complete Expository Dictionary of Old and New Testament Words, peny., W. E. Vine, Merrill F. Unger \& William White (Nashville: Thomas Nelson Publisher, 1798), hlm. 277.

${ }^{18}$ Kejadian 4:10. Terjemahan langsung dari bahasa Ibrani. Dalam terjemahan LAI, hanya dikatakan "Darah adikmu itu berteriak kepada-Ku dari tanah."
} 
"voice" (suara). ${ }^{19}$ Hal yang menarik untuk diperhatikan dari penggunaan kata ini ialah bahwa dalam bahasa Inggris, kata 'sound' dapat diterjemahkan bunyi dan suara, tetapi kata voice tidak dapat diterjemahkan bunyi, hanya suara, atau kata 'suara' dapat diterjemahkan dengan kata 'voice' dan 'sound' sedangkan kata 'bunyi' hanya diterjemahkan dengan kata 'sound.'

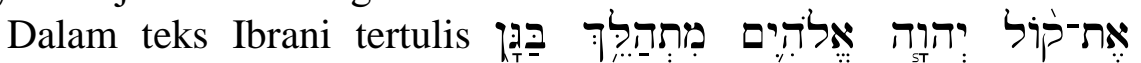

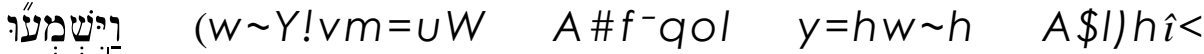
$<$ !fh $\sim$ @ $B \sim G^{`} n$ ) adapun terjemahan sederhana teks ini ialah "ketika mereka mendengar suara TUHAN Allah (sedang) berjalan

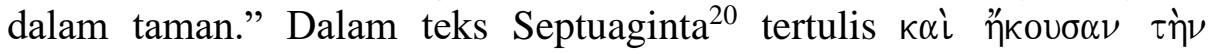

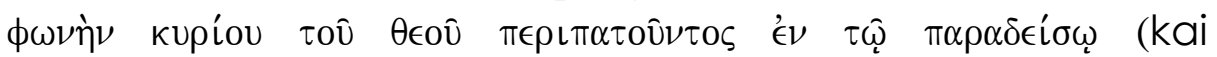
hkousan thn fwnhn kuriou tou qeou peripatountoj en tw paradeisw). Secara sederhana dapat diterjemahkan "ketika mereka mendengar suara Tuhan Allah \{selagi\} berjalan dalam firdaus." Dalam versi King James tertulis: "And they heard the voice of the LORD God walking in the garden in the cool of the day. Dalam versi ini kata qol diterjemahkan dengan "voice" (suara), sedangkan dalam versi New International Version, dikatakan demikian: Then the man and his wife heard the sound of the LORD God as he was walking in the garden in the cool of the day. Kata qol diterjemahkan bunyi "sound" (bunyi). Berbagai versi terjemahan ini tetap mengacu pada pemahaman ganda seperti yang diuraikan Sailhamer di atas.

Menurut Horatius Bonar, yang mereka dengar ialah suara TUHAN Allah. Menurutnya, ketika mendengar suara itu mereka gemetar

\footnotetext{
${ }^{19}$ Adapun terjemahan Inggris yang dimaksud ialah American Standard Version (ASV), (BBE), (KJG), (LXE), (RWB), (WEB). Diambil dari: Bible Work for Windows Copyright $\odot 2003$ Bible Works, LLC Version 6.0.005y WTM.

${ }^{20}$ Septuaginta adalah kitab suci Perjanjian Lama yang diterjemahkan dalam bahasa Yunani. Selama pemerintahan Ptolemius II Philadelphus (285 - 246 SM) proyek penterjemahan dari seluruh Kitab Suci orang Yahudi ke dalam bahasa Yunani dimulai oleh 70 atau 72 ahli-kitab Yahudi - menurut tradisi - 6 orang dipilih mewakili setiap dari 12 suku bangsa Israel. Terjemahan ini diselesaikan sekitar tahun 250 - 125 SM dan disebut Septuagint, yaitu dari kata Latin yang berarti 70 (LXX), sesuai dengan jumlah penterjemah. Kitab ini sangat populer dan diakui sebagai Kitab Suci resmi (kanon Alexandria) kaum Yahudi diaspora (=terbuang), yang tinggal di wilayah Asia Kecil dan Mesir. Pada waktu itu Ibrani adalah bahasa yang nyaris mati dan orang-orang Yahudi di Palestina umumnya berbicara dalam bahasa Aram. (Jeffry Komala http://www.catholic.com), diambil dari skripsi Bakho Jatmiko, STII, 2006.
} 
seketika itu karena telah mendengar suara itu sebelumnya tentunya dapat mengenali dengan baik. 'Itu adalah suara TUHAN! Dia datang ke manakah kita akan pergi?' Yang mereka dengar bukanlah sekedar bunyi; bukan bunyi yang kebetulan; itu adalah suara yang hidup; suara wujud sejati dan berpribadi seperti mereka. Bagi mereka Allah adalah wujud yang nyata, pribadi, dan suara-Nya adalah suara yang nyata. Lebih jauh ia menghubungkan antara suara itu dengan logos, menurutnya logos tidak hanya muncul dengan cara yang kelihatan, tetapi juga berbicara kepada Adam dan Hawa, terdengar, dan dengan ucapan suara yang jelas (artikulasi). ${ }^{21}$

Kata "voice" digunakan dalam Alkitab dengan beberapa arti. Terkadang menunjukkan artikulasi bunyi yang berbeda (Ul. 4:12,36; 5:22; Yeh. 1:24,25,28; 10:5); firman (sesuatu yang dinyatakan melalui suara); guntur (thunder) (bunyi yang menyertai suara) (Kel. 9:23,28,29; Ayub 37:5). Suara inilah yang berbicara kepada Kain (Kej. 4:9), kepada Nuh (Kej. 6:13), kepada Abraham (Kej. 15:1). Ketika Musa berbicara, Tuhan menjawabnya dengan suara ${ }^{22}$ (Kel. 19:19). Itu adalah suara Allah yang mengguncangkan Sinai dan padang belantaranya, yang menggoncangkan ambang pintu (Yes. 6:4), melalui suara inilah bangsa Asyur dikalahkan (Yes. 30:31). Ini adalah suara yang didengar oleh Yesaya (Yes. 6:4), dan Yehezkiel (Yeh. 1:24; 10:5,9), dan Daniel (10:6). Suara yang sama ini jugalah yang terdengar pada pembaptisan Yesus (Mat. 3:17) dan pada saat transfigurasi (Mat. 17:5). Memang sangat menarik mempelajari kata "voice" dalam kitab suci. Terkadang sangat dashyat seperti guntur, terkadang hanya suara kecil, terkadang seperti kegaduhan orang banyak, terkadang seperti riak air. ${ }^{23}$ Tanpa memberikan alasan yang jelas, H. C. Leupold juga menyetujui bahwa bunyi yang didengar Adam dan Hawa bukanlah bunyi langkah TUHAN, melainkan suara TUHAN. ${ }^{24}$

Ide yang kontras dengan uraian di atas terdapat dalam pembahasan Davis, dalam bukunya Eksposisi Kitab Kejadian, yang mengatakan bahwa Adam dan Hawa mendengar bunyi langkah TUHAN Allah yang

${ }^{21}$ Horatius Bonar, Thoughts on Genesis (Grand Rapids: Kregel Publications, 1979), hlm. 133-134.

${ }^{22}$ Terjemahan LAI ialah "dengan guruh."

${ }^{23}$ Bonar, Thoughts on Genesis, hlm. 133-134.

${ }^{24}$ H. C. Leupold, Exposition of Genesis (Grand Rapids: Baker Book House, 1982), hlm. 1:155. 
berjalan-jalan dalam taman itu. ${ }^{25}$ Secara implisit namun jelas, Wenham mendukung ide ini ketika melakukan eksposisi bagian ini. ${ }^{26}$ Namun baginya, langkah Allah yang berjalan yang didengar oleh Adam dan Hawa pada waktu itu tidak dapat dipahami dengan langkah biasa. Penulis mengamati setidaknya dua hal yang melatarbelakangi pemikiran Wenham ketika ia menekankan konteks ini tidak dapat dipahami dengan biasa/ normal, yaitu: pertama, Deskripsi taman Eden dengan pepohonan, sungai-sungai, emas dan lainnya menekankan kehadiran Allah di sana.

Oleh karena itu, ketika Allah berjalan dan mereka mendengar dengan membawa reaksi tentu ini disertai dengan nuansa yang tidak biasanya. Adalah mungkin terbiasa bagi mereka untuk mendengar suara maupun langkah Allah sebelumnya, kedua, ialah kondisi mereka yang telah berdosa yang tampak pada reaksi mereka terhadap diri mereka sendiri (mengetahui bahwa mereka telanjang), reaksi mereka terhadap Allah (bersembunyi ketika menyadari kehadiran Allah). ${ }^{27}$ Sebab memang sebelumnya adalah mereka telanjang, namun tidak merasa malu, dan memang sebelumnya mereka adalah bersama dengan Allah namun tidak bersembunyi. Pemahaman terhadap kondisi inilah yang membawa Wenham untuk menekankan nilai perbedaan bentuk langkah Allah.

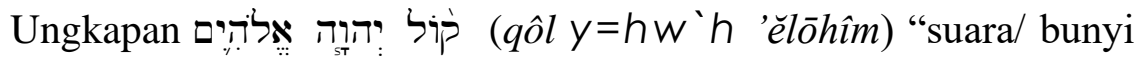
TUHAN Allah" adalah ungkapan yang umum ditemukan dalam kitab Pentateukh, khususnya kitab Ulangan $(5: 25 ; 8: 20 ; 13: 18 ; 15: 5 ; 18: 16$; $26: 14 ; 27: 10 ; 28: 1,2,15,45,62 ; 30: 8)$. Lazimnya ungkapan ini selalu berhubungan dengan panggilan ketaatan kepada TUHAN. ${ }^{28}$ Dalam Ulangan 5:25 dan 18:16 (bdk. Kel. 20:18-21), ketika Tuhan datang ke Sinai, bangsa Israel mendengar bunyi YHWH. Adapun respon bangsa Israel mendengar bunyi YHWH itu sama seperti respon Adam dan Hawa pada waktu mendengar bunyi TUHAN Allah, mereka takut dan berdiri jauh-jauh dan berkata “... janganlah Allah berbicara dengan kami, nanti kami mati” (Kel. 20:18-19). Demikian juga Adam dan istrinya berusaha melarikan diri ketika mendengar suara Allah. ${ }^{29}$ Tindakan mereka itu lahir ketika mereka tidak taat kepada Allah,

${ }^{25}$ Davis, Eksposisi Kitab Kejadian, 97.

${ }^{26}$ Wenham, "Genesis," dalam Word Biblical Commentary 1-15, hlm. 1:76.

${ }^{27}$ Wenham, "Genesis," dalam Word Biblical Commentary 1-15, hlm. 1:76.

${ }^{28}$ Sailhamer, "Genesis," dalam The Expositor's Bible Commentary, hlm. 52.

${ }^{29}$ Sailhamer, "Genesis," dalam The Expositor's Bible Commentary, hlm. 52. 
sebaliknya mereka justru melakukan apa yang diperintahkan ular. Dalam konteks ini, kehadiran suara Allah sangat berkaitan dengan ketidaktaatan mereka. Jadi, suara Allah sering terdengar manakala ketidaktaatan manusia timbul.

Dari pemahaman teks pada ayat 8, lebih mendukung pada bunyi yang dihasilkan oleh suara kaki Allah yang berjalan. Kalau dikatakan menunjuk pada suara Allah, penulis tidak setuju karena Allah memulai pembicaraan-Nya dengan memanggil Adam pada ayat 9. Jika dikatakan suara Allah bergema melalui guntur atau badai, penulis sangat sulit menerima ini karena teks sendiri tidak mengatakan demikian. Mungkin uraian kronologis yang disajikan dalam teks dapat menolong, yaitu ketika Allah berjalan dalam taman, mereka mendengar (bunyi kaki Allah) lalu mereka bersembunyi. Persembunyian mereka inilah yang melahirkan pertanyaan Allah "Di manakah engkau?" Tindakan persembunyian yang mendahului pemanggilan Allah dengan jelas menunjukkan bahwa bukan karena suara Allah mereka bersembunyi, melainkan karena bunyi kaki Allah. Jadi secara gramatikal pendengaran mereka adalah aktivitas pendengaran yang telah berlangsung (perfek) namun masih berdampak pada mereka, yang terwujud dalam tindakan persembunyian.

\section{INTERPRETASI LEKSIKAL}

Kata $\vee^{*} m \wedge \mathrm{u}$ pada umumnya diartikan mendengar. Kata $u \mathrm{~m}^{\wedge} \mathrm{v}^{*}$ $\left(\vee^{*} \mathrm{~m} \wedge \mathrm{U}\right)$ memiliki beberapa makna yang tergantung pada stemnya. Dalam bentuk qal memiliki arti mendengar, mendengarkan, memperhatikan, merasa, mengerti, mematuhi, mengabulkan, menguji; Dalam bentuk niphal memiliki arti didengarkan, dipatuhi, dan dikabulkan; dalam bentuk piel memiliki arti memanggil; dalam bentuk hifil berarti menyebabkan seseorang untuk mendengar, menyatakan, mengumumkan, memangggil. ${ }^{30}$ Arti lain dari kata ini ialah mematuhi dan menerbitkan. Kata ini terdapat dalam bahasa Semitik termasuk dalam Alkitab Ibrani dan Aramik. Kata $\vee^{*} m \wedge u$ terdapat dalam seluruh

${ }^{30}$ K. T. Aitken "um^v," dalam New International Dictionary of Old Testament, hlm. 4:175 
sejarah Ibrani dan kurang lebih digunakan 1.160 kali dalam Alkitab, dan 9 kali dalam bahasa Aram. ${ }^{31}$

Arti dasar kata ini ialah "mendengarkan" sesuatu dengan telinga, ${ }^{32}$ tetapi terdapat juga beberapa penggunaan dengan nuansa lain. Dalam Kejadian 37:17 seorang pria berkata kepada Yusuf bahwa ia telah mendengar saudara-saudara Yusuf berkata "marilah kita pergi ke Dotan," dengan kata lain dia tanpa sengaja mendengar perkataan mereka. Kata $\mathrm{v}^{*} \mathrm{~m} \wedge$ udapat juga digunakan untuk mendengarkan sesuatu yang seharusnya tidak boleh didengar, tetapi dapat juga digunakan untuk mendengarkan dengan sengaja; Sarah secara diamdiam mendengarkan apa yang dikatakan ketiga orang yang datang kepada Abraham (Kej. 18:10).

Dalam 1 Tawarikh 28:2, Daud berkata kepada seluruh pembesar Israel untuk 'mendengarkannya' ketika ia berbicara, mereka memberikan perhatian mereka sepenuhnya. Dalam kitab nabi-nabi (khususnya Yeremia), mendengar bunyi adalah sebuah motif yang berulang kali dalam deskripsi penghukuman melalui bencana militer. Dengusan kuda (Yer. 8:16), bunyi terompet, dan teriak peperangan $(4: 19,21)$ adalah tanda kedatangan musuh. Dalam konteks teofani Ilahi, mendengar guntur adalah mendengarkan suara keagungan Allah (Yes. 30:30). Penyataan Allah dalam badai dijelaskan dalam nada mendidik oleh Elihu: "manusia harus mendengar pada gegap gempita suara-Nya" (Ayb. 37:2), karena Dia adalah Allah yang ajaib (14), melebihi pengetahuan manusia (5), yang menuntun mereka untuk mengetahui perbuatan-Nya (7) dan memuja Dia (24). Selain mendengarkan langsung perkataan, $\mathrm{v}^{*} \mathrm{~m} \wedge \mathrm{U}$ juga digunakan dalam hal mempelajari sesuatu, diberitahukan (Kej. 21:26; 42:2). Dalam beberapa bagian $\mathrm{V}^{*} \mathrm{~m} \wedge \mathrm{U}$ berarti mendengarkan dengan penuh perhatian, memperhatikan. Dapat dilakukan dengan menyendengkan telinga (Mzm. 45:11). Dalam Yehezkiel 40:4 diperkuat dengan cym I@B, mempersiapkan hati, pikiran (dengarlah dengan telingamu dan

\footnotetext{
${ }^{31}$ Archer dan Lainnya, "hear," dalam Vine's Complete Expository Dictionary, hlm. 107.

${ }^{32}$ Aitken "umv,", dalam New International Dictionary of Old Testament Theology, hlm. 4:175.
} 
perhatikanlah, bnd. 44:5). Memperhatikan berarti mewajibkan pendengar untuk diam (Ul. 27:9; ay. 29:21). ${ }^{33}$

Dengan hadirnya unsur pikiran dalam penggunaan kata $v^{*} m \wedge u$, selanjutnya kata ini juga digunakan dalam arti mengerti dan merasa. Karena itu dapat dihubungkan dengan istilah mengenal (yDU) dan mengetahui (byn). Kegagalan Israel untuk memahami penyataan Allah dapat dinyatakan dengan ketidakmampuan telinga mereka untuk mendengar (Ul. 29:4; Yes. 6:9). vmujuga digunakan dalam pengertian bahasa. Pengacauan bahasa di Babel mengakibatkan orang-orang tidak dapat mengerti satu dengan lainnya (Kej. 11:7; bndk. Yes. 36:11). Dalam konteks yang berbeda, vmu berarti mendengarkan, memperhatikan dengan melakukan sesuatu, atau mempraktekkan apa yang telah dikatakan. Dalam konteks ini sinonim dengan $\mathrm{UCH}$ melakukan ("Musa mendengarkan mertuanya dan melakukan semua yang dikatakan" (Kel. 28:24). Di mana pendengar menjadi subyek bagi otoritas pembicara, sangat erat hubungannya dengan pengertian "menaati/ mematuhi." Ketaatan kepada seseorang sering dinyatakan melalui $v m u B=q o l$ (secara literal diterjemahkan "mendengarkan suara dari " (U1. 21:18 [orang tua]; 1 Sam. 28:21 [raja]; Kej. 26:5 [Allah]. Konstruksi kata vmu dengan (A\#T, I=, $A \backslash I, B=q o l$, I=qol) adalah tidak jelas / sulit untuk membedakan antara mendengarkan dan melakukan. ${ }^{34}$ Karena itu sulit memutuskan apakah mendengarkan dengan kemauan dan perhatian yang termanifestasi dalam ketaatan atau apakah itu hanya menunjukkan ketaatan dengan motivasi tertentu.

Konteks mendengar ini juga membingkai hubungan Israel dengan Allah. Diatas segalanya, Israel harus mendengar dan menaati Allah. Dalam 1 Samuel 15:22 terdapat prinsip alkitabiah mengenai ketaatan, yaitu "mendengarkan lebih baik daripada korban sembelihan." Mendengarkan dan mematuhi terdapat dalam respon Israel kepada pengajaran Allah yang diberikan melalui pada nabi (bndk. Hag. 1:12). Kemampuan Allah untuk mendengar dan bertindak (bndk. Dan. 9:19) memposisikan Allah jauh berbeda dari ilah-ilah yang terbuat dari kayu dan batu yang tidak dapat melihat dan mendengar (Ul. 4:28; Mzm.

\footnotetext{
${ }^{33}$ Aitken "um^v," dalam New International Dictionary of Old Testament Theology, hlm. 4:175.

${ }^{34}$ Aitken, "um^v," dalam New International Dictionary of Old Testament Theology, hlm. 178.
} 
115:6). Dalam suatu kesempatan, Allah meresponi apa yang didengarNya dengan memberikan penghukuman (dalam konteks kejahatan), misalnya ketika Allah mendengar sungut-sungut bangsa Israel di padang gurun (Ul. 11:1; 14:27; Mzm. 78:21). Akan tetapi sering juga, Allah meresponi terhadap hal yang didengar-Nya dengan bertindak untuk menolong dan menyelamatkan. Dalam kehidupan bapa-bapa leluhur, pendengaran Allah sering dihubungkan dengan kelahiran anak (Kej. 30:6; 17, 22), termasuk kelahiran Ismail (16:11) dan Simeon (29:30). Dalam peristiwa keluaran, Allah memperhatikan teriakan bangsa Israel untuk dilepaskan dari perbudakan, dan Allah membebaskan mereka (Kel. 2:24; 3:7; 6:5; Ul. 26:7). Allah juga adalah pribadi yang mendengarkan setiap doa (Mzm. 65:3). Dalam konteks ini kata vmu berarti mengabulkan, dan sinonim dengan Unh, yang artinya menjawab dan mengabulkan. ${ }^{35}$

Mendengarkan sesuatu dapat mengimplikasikan "adanya pengetahuan (intelligently), ${ }^{36}$ " seperti ketika Abimelek berkata kepada Abraham bahwa ia tidak mengetahui peristiwa perampasan sumur oleh hamba-hamba Abimelek, karena tidak seorangpun mengatakan kepadanya, dan dia juga belum pernah mendengar (Kej. 21:26). Kata $\mathrm{V}^{*} \mathrm{~m} \wedge \mathrm{U}$ dapat juga mengimplikasikan peningkatan pengetahuan atau memperoleh pengetahuan; ketika orang-orang Kasdim mendengar bahwa tentara Firaun telah berangkat dari Mesir mereka angkat kaki dari Yerusalem (Yer. 37:5). Kata ini dapat berarti mendatangkan pengetahuan tentang sesuatu. Musa berkata kepada orang-orang yang najis untuk menunggu sementara ia mendengarkan pada apa yang akan diperintahkan TUHAN mengenai orang-orang itu (Bil. 9:8). Maksud Musa dalam hal ini adalah jelas, bahwa ia tidak hanya akan mendengarkan, tetapi dia bermaksud untuk mendapatkan pengetahuan dari TUHAN.

Mendengarkan dapat mengandung nilai intelektual dan spiritual. Nilai spiritual, yaitu ketika seseorang mendengarkan Firman Allah (Bil. 24:4), atau mempelajari sesuatu dari Allah. Sebaliknya, Allah berkata kepada Abraham bahwa Dia telah mendengarkan doa Abraham dan akan bertindak (Kej. 17:20). Dalam konteks ini, mendengar berarti

\footnotetext{
${ }^{35}$ Aitken, "um^v*," dalam New International Dictionary of Old Testament Theology, hlm. 180.

${ }^{36}$ Rick Meyers, Strong `s Hebrew and Greek Dictionaries. e-Sword-the Sword of the LORD with an electronic edge, 2004. [CD-ROOM].
} 
tidak hanya mendengar apa yang dikatakan, tetapi setuju dengan maksud dan permohonan yang diucapkan (bndk. Kej. 16:11). Dalam hal mendengar pada otoritas yang lebih tinggi, kata $\mathrm{v}^{*} \mathrm{~m} \wedge$ udapat berarti 'mematuhi.' Melalui keturunan Abraham, semua bangsa akan diberkati karena dia mendengarkan (menaati) suara Tuhan (Kej. 22:18). ${ }^{37}$ Selanjutnya ialah nilai intelektual dari mendengarkan, yaitu ketika mendengarkan suatu hal, seseorang dapat mendapatkan berbagai informasi, semakin banyak informasi yang diperolehnya, maka semakin luas wawasan intelektualnya. Dengan demikian, secara leksikal kata $\mathrm{V}^{*} \mathrm{~m} \wedge$ Udalam konteks ini adalah tindakan pendengaran secara literal yang dilakukan oleh indrawi sebagai reaksi terhadap tindakan yang dari luar (dalam konteks ini adalah bunyi kaki Allah).

Setelah mempelajari penggunaan kata $\vee^{*} m \wedge u$ dan konteks yang mengikutinya dapat disimpulkan bahwa kata $V^{*} m \wedge U$ merupakan bentuk pendengaran yang selalu membawa dampak. Terhadap setiap penggunaan ini selalu ada reaksi ataupun hasil yang diperoleh. Baik berupa pengetahuan, wawasan maupun berupa reaksi seperti bersembunyi, ketakutan, menghindar dan sebagainya. Dalam konteks ini, pendengaran Adam ini adalah suatu pendengaran, yang mengandung pengetahuan yang berdampak secara psikologis (takut) yang akhirnya melahirkan reaksi bersembunyi. Tidak sebatas pendengaran, namun pendengaran ini yang memberitahu dan menyadarkan mereka akan kehadiran Allah. Jelas ini menunjukkan kehidupan persekutuan dan komunikasi yang baru antara Allah dengan mereka. Secara spiritual mereka tidak dapat langsung merasakan kehadiran Allah, kehadiran Allah hanya dirasakan dan diketahui dengan sentuhan indra.

\section{Studi kata "Bersembunyi" $\left(a b^{*} j^{*}\left[j^{*} b^{*} a\right]\right)$}

Kepentingan kepenulisan dalam mengungkapkan makna kata "bersembunyi" (ab*j* j*b*a) ialah menjelaskan upaya yang dilakukan oleh Adam dan Hawa di tengah-tengah keberdosaan mereka. Apakah reaksi Allah dan sejauh mana mereka dapat melakukan persembunyian. Lebih dari sekedar menguraikan definisi kata, penulis ingin

${ }^{37}$ Archer dan Lainnya, "hear," dalam Vine's Complete Expository Dictionary, hlm. 107-108. 
mengungkapkan gagasan ide dari kata dan tindakan bersembunyi. Kajian ini setidaknya juga akan dikontribusikan dalam nilai-nilai praktis dalam pembahasan berikutnya.

\section{INTERPRETASI GRAMATIKAL}

Kata bersembunyi berasal dari kata dari kata dasar $\boldsymbol{T}_{\mathrm{T}}\left(\mathrm{j}^{*} \mathrm{~b}^{*} \mathrm{a}\right)$. Rangkaian kata ini diikuti oleh konjungsi $\mathrm{w}^{\wedge}(\mathrm{W} \sim)$, yang dalam konteks ini berfungsi menyatakan akibat, ${ }^{38}$ sehingga lebih tepat diterjemahkan "maka." Adapun alasannya ialah karena persembunyian yang dilakukan oleh Adam dan Hawa adalah sebagai akibat dari bunyi kehadiran Allah yang mereka dengar. Teks LAI memang tidak menerjemahkan konjungsi ini, akan tetapi sebagian besar Alkitab Versi Inggris ${ }^{39}$ menerjemahkan konjungsi ini dengan kata "and" (dan), dan Septuaginta ${ }^{40}$ menerjemahkannya dengan "kal" (kai) yang juga dapat diterjemahkan "dan,"hanya versi New Living Translation (NLT) yang menerjemahkan konjungsi ini dengan kata "so" (maka/ sehingga), dan hanya versi The New American Bible (NAB) yang sama dengan terjemahan LAI, yakni tidak menerjemahkan konjungsi $\mathrm{W}^{\wedge}(\mathrm{W} \sim)$.

$W \sim Y ! \dagger j \sim B @ A$ adalah jenis kata kerja hitpael dengan stem imperfek. Adapun fungsi utama dari hitpael adalah untuk menunjukkan arti refleksif atau resiprokal dari pangkal piel, dan fungsi kedua ialah menunjukkan arti pasif. Sedangkan pemakaian hitpael digunakan untuk menyatakan refleksif ${ }^{41}$ (subyek [tunggal/ jamak] berbuat atas dirinya

\footnotetext{
${ }^{38}$ Reed dan Sedi, Diktat Kuliah.

${ }^{39}$ Sebagian besar Alkitab versi Inggris yang dimaksudkan ialah American Standard Version (ASV), The Bible in Basic English (1949/64 (BBE), King James with Strong's and Geneva Notes (KJG), LXX English Translation (Brenton (LXE), English Standard Version (2001 (ESV), New American Standard Bible with Codes (1995 (NAU), New International Version (BR (NIB), New International Version (1984 [US] NIV), The New Jerusalem Bible (NJB), New King James Version (1982 (NKJ), New Revised Standart Version (1989 NRS), Revised Standart Version (1952 RSV), Revised Webster Update (1995) with Codes (RWB), The Webster Bible (1833 (WEB), Young's Literal Translation (1862/ 1898 (YLT). Diambil dari Bible Work for Windows Copyright (C) 2003 Bible Works, LLC Version 6.0.005y WTM.

${ }^{40}$ LXX Septuaginta Rahlfs' (LXT) dan Modern Greek Bible (MGK).

${ }^{41}$ Terdapat 4 jenis refleksif yaitu: pertama, refleksif langsung, di mana subyek adalah obyek langsung dari tindakan kata kerja; kedua, refleksif tidak langsung, di mana subyek adalah obyek tidak langsung dari tindakan kata kerja; refleksif
} 
sendiri dan resiprokal (subyek jamak bertindak berbalasan atas sesama). Hal ini terjadi jika dua (atau lebih) subyek bertindak dalam hubungan bersama sesuai dengan yang dinyatakan oleh kata kerja. Bentuk-bentuk pemakaian hitpael ialah pertama, pemakaian pasif: arti pasif dari pangkal hitpael dapat menunjukkan (a) pengertian bahwa subyek diubahkan atau ditindakkan oleh sesuatu yang tidak disebut, atau (b) pengertian bahwa subyek mengubahkan dirinya ke dalam keadaan tersebut. Dalam pemakaian bahasa Ibrani Alkitab, arti hitpael hampir selalu mengandung arti refleksif/ resiprokal. Hanya dalam perkembangan selanjutnya, hitpael mulai lebih sering diterjemahkan dengan arti pasif; kedua, pemakaian iteratif (frekuentatif), dan ketiga, pemakaian denominatif, terkadang dipakai untuk mengubah kata benda menjadi kata kerja. ${ }^{42}$ Dari seluruh penggunaan hitpael, dalam konteks ini fungsi hitpael menunjukkan arti refleksif, yaitu mereka menyembunyikan diri mereka sendiri. Pemakain refleksif dalam konteks ini menunjukkan refleksif langsung, di mana mereka menjadi obyek tindakan kata kerja (bersembunyi). Sehingga dalam bagian ini

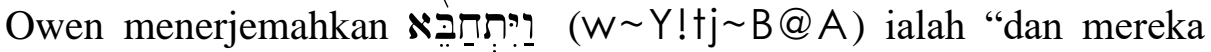
menyembunyikan diri mereka sendiri” (and hid themselves). ${ }^{43}$ Ide yang berkembang dari penggunaan hitpael dalam konteks ini ialah bahwa persembunyian itu adalah upaya penyelamatan diri (dari ketakutan) yang dilakukan dengan kesadaran penuh. Nilai kesadaran penuh ini dibangun atas orientasi pada diri sendiri, yaitu upaya menyelematkan diri sendiri.

Pada penggunaan kedua kata bersembunyi ini, tetap memiliki gagasan utama yang sama dengan kata pertama. Kata bersembunyi yang kedua (ay.10) juga berasal dari kata kerja yang sama. Akan tetapi jenis kata kerja yang kedua ialah nifal. Kendati dalam bentuk nifal namun tetap menyatakan diatesis refleksif, di mana subyek dan obyek dari kata kerja adalah sama, atau berhubungan dengan orang atau hal

benefaktif, yang berhubungan dengan tindakan yang dilakukan bagi dirinya sendiri; dan refleksif estimatif-deklaratif, yang sejajar dengan piel yang menganggap atau mengumumkan seseorang adalah dalam keadaan tertentu (Diambil dari: Reed dan Sedi, Diktat Kuliah).

${ }^{42}$ Terdapat 4 jenis refleksif yaitu: pertama.

${ }^{43}$ John Joseph Owens, Analytical Key to the Old Testament, (Grand Rapids: Baker Book House, 1995), Genesis-Joshua hlm. 1:11. 
yang sama. Sehingga lebih tepat diterjemahkan "aku menyembunyikan diriku sendiri" (and I hid myself). ${ }^{44}$

Dalam Perjanjian Lama, kata j*b*a dalam berbagai variasi penggunaan terdapat 34 kali sebagai kata kerja. Kata kerja ini muncul dalam bentuk nipal: diterjemahkan menyembunyikan diri sendiri, hipil diterjemahkan menyebabkan seseorang menyembunyikan dirinya sendiri, bentuk pual, hopal dan hitpael tidak terlalu menunjukkan karakteristiknya. ${ }^{45}$ Kata $j^{*} b^{*}$ a umumnya selalu menunjuk pada orang (persons). Sebanyak 26 kali penggunaannya menunjuk pada orang yang menyembunyikan diri mereka sendiri atau menyembunyikan orang lain dari ketakutan akan kematian. ${ }^{46}$ Tindakan bersembunyi (j*b*a) biasanya terjadi dalam konteks pengejaran. Tujuannya ialah untuk mendapatkan keselamatan/ keamanan ketika musuh tidak dapat diatasi lagi. Bersembunyi berarti melarikan diri dari genggaman seseorang, menghilang dari pandangan seseorang. ${ }^{47}$

Kata "bersembunyi" dapat digunakan secara literal dan figuratif. Sebagian besar penggunaan kata j*b*a dalam bentuk nipal dan hipil, keduanya digunakan secara literal. Pada peristiwa pengintaian dalam Yosua 2, Rahab menyuruh kedua pengintai dari Israel untuk menyembunyikan diri mereka (ay. 16 [dalam bentuk nipal]) ke pegunungan dari para pengejar yang diutus oleh raja kota Yerikho. Rahab telah terlebih dahulu menyembunyikan mereka di sotoh rumahnya. $^{48}$

Konteks penggunaan kata ini terdapat pada peristiwa Yakub menyembunyikan dirinya dengan melarikan diri dari Laban (Kej. 31:27). Orang-orang Ibrani menyembunyikan diri mereka dari orang Filistin (1 Sam. 13:6; 14:22). Demikian juga Daud menyembunyikan dirinya dari kemarahan raja Saul (1 Sam. 19:2; 23:23). Akan tetapi

\footnotetext{
${ }^{44}$ Versi Inggris yang tidak menerjemahkan diatesis refleksi ialah NIV, NIB, NJB, dan NLT, selebihnya menerjemahkan dengan kata -myself.

${ }^{45}$ Siegried Wagner dan Leipzig, "ab*j," dalam Theological Dictionary of the Old Testament, peny., G. Johanes. Botterweck dan Helmer Ringgren, pen., David E. Green (Grand Rapids: William B. Eerdmans Publishing, 1978), hlm. 4:165.

${ }^{46}$ Andrew E. Hill, "ab*j**," dalam New International Dictionary of Old Testament, hlm. 2:1.

${ }^{47}$ Wagner dan Leipzig, "ab*j," dalam Theological Dictionary of the Old Testament, hlm. 4:165.

${ }^{48}$ Wagner dan Leipzig, "ab*j," dalam Theological Dictionary of the Old Testament, hlm. 4:166.
} 
bersembunyi tidaklah selalu menjadi jaminan keselamatan seperti yang terjadi pada kelima raja yang bersekutu melawan Yosua, walaupun mereka bersembunyi mereka tetap binasa (Yos. 10:16,17,27). Bangsa Israel berusaha untuk bersembunyi dari penghakiman Allah, namun semuanya sia-sia saja (Ams. 9:3).

\section{Interpretasi Leksikal}

Kata bersembunyi berasal dari kata jba yang merupakan rumpun bahasa semitik. Arti dasar kata ini diterjemahkan dalam bahasa Inggris "hide" atau "conceal." 49 Kata jba menunjukkan suatu upaya melarikan diri dari para penyerang atau pengejar dengan bersembunyi agar dapat menghilangkan diri dari hadapan pengejar atau menjadi tidak terdeteksi (undetectable), dan hampir tidak kelihatan sama sekali. Makna lain dari kata ini juga menunjuk pada persembunyian karena takut akan kehadiran Allah, apakah karena malu atau merasa bersalah (Kej. 3:8, 10; konteks ini merupakan bahasan utama) atau ketakutan yang besar (Dan. 10:7). ${ }^{50}$ Ide ini sesuai dengan pernyatan Alders yang menyatakan bahwa kehadiran Allah memenuhi manusia itu dan isterinya dengan ketakutan, ${ }^{51}$ adanya perasaan dan kesadaran inilah yang membuat mereka menyembunyikan diri. Transendensi dan kekudusan Allah menjadi ancaman bagi manusia dalam upaya menghindari Pencipta mereka.

Terdapat banyak kata dalam bahasa Ibrani yang menyatakan ide mengenai persembunyian dalam Perjanjian Lama. Terutama kata jba (bersembunyi: melarikan diri dengan rahasia); $\mathrm{fmn}$ (bersembunyi: dengan mengubur); KjD (bersembunyi/ menyembunyikan: dengan menolak menyatakan sesuatu); sTr (bersembunyi/ menyembunyikan, disembunyikan: khususnya dalam konteks Allah menyembunyikan wajah-Nya dari dosa manusia); UIm (bersembunyi, menjaga rahasia); dan JPn (bersembunyi/ menyembunyikan: untuk perlindungan). Dalam aspek teologis, dasar kata-kata di atas menekankan dua aspek

\footnotetext{
${ }^{49}$ Wagner dan Leipzig, "ab*j," dalam Theological Dictionary of the Old Testament, hlm. 4:166.

${ }^{50}$ Hill, "ab*j**," dalam New International Dictionary of Old Testament, hlm. 2:2

${ }^{51}$ G. Ch. Aalders, "Genesis," dalam Bible Student's Commentary, pen., William Heynen (Grand Rapids: Zondervan Publishing House, 1981), hlm. 1:103.
} 
natur Allah: kemahatahuan Allah, di mana tidak ada sesuatupun yang dapat disembunyikan atau dirahasiakan dari-Nya; dan kebaikan Allah: sebagaimana Dia menyembunyikan (dari kejahatan), tempat perteduhan, dan melindungi orang yang benar. ${ }^{52}$

Wagner meringkaskan idenya "akar kata jba merupakan sebuah tindakan manusia yang ditentukan baik secara rasional maupun irasional dengan tujuan untuk memelihara/ mempertahankan hidup. ${ }^{53}$ Konsep ini tidak hanya melibatkan elemen-elemen gerakan tetapi juga elemen-elemen yang menjadikan tidak kelihatan. Bersembunyi masuk ke dalam suatu tempat, sebuah tempat persembunyian yang memungkinkan untuk tidak kelihatan.

Setelah mempelajari kata "bersembunyi" dari akar kata jba dan penggunaannya, maka dalam konteks ini persembunyian yang dilakukan Adam dan Hawa ialah tindakan yang dilakukan dengan penuh kesadaran, sebagai upaya penyelamatan diri dari perasaan takut akan kehadiran Allah, ketakutan yang disertai dengan perasaan malu namun tanpa perasaan bersalah. Yang semuanya lahir ketika pertama mereka mendengar kehadiran Allah dalam taman Eden. Kendati Adam mengedepankan rasa takut dalam jawabannya, namun tujuan utama persembunyiannya ialah untuk menyembunyikan perbuatan dosa yang telah dilakukannya. Bersembunyi dari Allah adalah upaya untuk meniadakan tanggung jawab dan menghindari konsekuensi perbuatan mereka. ${ }^{54}$ Bahkan ketika Allah mendatangi Adam dan bertanya langsung ia juga berupaya berdalih dengan meniadakan unsur-unsur kesalahan atau pelanggaran dalam jawaban yang diberikan kepada Allah.

Upaya Adam untuk menyembunyikan diri adalah sia-sia, sebab bagaimanapun juga Allah pasti mengetahui. Karena tindakan ini dilakukannya terhadap Allah. Persembunyian adalah suatu tindakan yang hanya dapat dilakukan terhadap sesama manusia. Allah sungguh mengetahui keberadaan mereka. Di tengah-tengah upaya persembunyian mereka inilah Allah memanggil mereka dengan mengajukan rangkaian pertanyaan.

\footnotetext{
${ }^{52} \mathrm{Hill}$, " $\mathrm{ab} \mathrm{b}^{* *},{ }^{*, "}$ dalam New International Dictionary of Old Testament Theology, hlm. 2:2.

${ }^{53}$ Ibid.

${ }^{54} \mathrm{R}$. Payne Smith, "Genesis," dalam Ellicott's Commentary on the Whole Bible, peny., Charles John Ellicott (Grand Rapids: Zondervan Publishing House), GenesisNumbers, hlm. 1:24.
} 


\section{Studi Teks Model-model Pertanyaan Tuhan}

Dalam mengungkapkan kebenaran teologis di balik pertanyaan Allah kepada Adam dan Hawa, penulis menaruh perhatian penuh terhadap studi teks ini. Studi teks yang dilakukan terhadap pertanyaan Allah ini lebih terfokus kepada kalimat tanya yang digunakan oleh penulis kitab, ketika Allah mengajukan rangkaian pertanyaan. Selain isi pertanyaan, gaya bahasa dalam bertanya juga sangat mempengaruhi arah dan tujuan pertanyaan. Inilah yang mendorong penulis untuk melakukan studi teks. Hingga tiba pada tujuan akhirnya dapat memberikan suatu kontribusi teologis terhadap makna pertanyaan Allah.

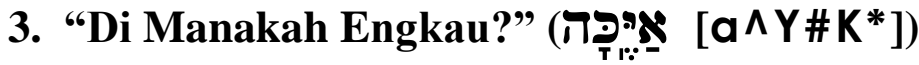

Di tengah-tengah persembunyian Adam dan Hawa di antara pohon-pohonan dalam taman Eden, karena Adam dan Hawa sudah tahu bahwa mereka tidak berbusana (telanjang), karena itu Adam dan Hawa takut bertemu dengan Tuhan, tetapi dalam taman Eden TUHAN Allah memanggil mereka. Allah justru memberikan pertanyaan kepada

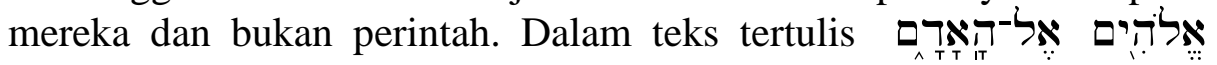

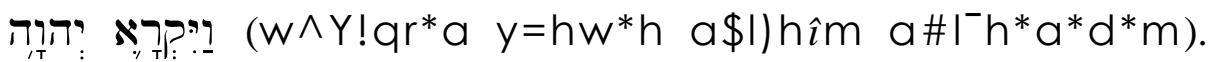
Kata memanggil yang digunakan berasal dari kata dasar $\boldsymbol{N}_{T}\left(\mathrm{q}^{*} \mathrm{r}^{*} \mathrm{a}\right)$ dalam bentuk imperfek. Konjungsi ? (wa) ${ }^{55}$ dalam teks LAI

\footnotetext{
${ }^{55}$ Adapun fungsi konjungsi I ialah sebagai koordinasi, dengan arti "dan" "kemudian," sebagai disjunktif (menunjukkan kontras dengan bagian sebelumnya), menunjukkan perlawanan (adversative), dengan arti "tetapi," menunjukkan pilihan antara hal (alternative), dengan arti "atau," menambah penjelasan (explicative), dengan arti "yakni," sebagai waw pleonasme (hanya untuk gaya bahasa, tidak ada arti khusus), dipakai dengan arti beserta (accompaniment), diterjemahkan "bersama dengan," menunjukkan perbandingan, tetapi hanya dalam puisi, diterjemahkan "seperti," untuk menekankan, dengan arti "bahkan," untuk menunjukkan sarkasme, menyatakan akibat (apodosis) dalam kalimat bersyarat, menunjukkan penambahan (adjunctive) dengan arti "juga," dan dipakai dengan makna distribusi, dengan arti "masing-masing” atau "setiap."(Diambil dari: Reed dan Sedi, Diktat Kuliah: Bahasa Ibrani Jilid III, hlm. 107-108.
} 
diterjemahkan dengan "tetapi," menurut penulis lebih tepat diterjemahkan "kemudian"56 karena gagasan pada ayat 9 bukan dipertentangkan dengan ayat 8 melainkan menjelaskan peristiwa lain yang terjadi yaitu "TUHAN Allah memanggil."

Kata ${ }{ }^{*} q^{*}\left(q * q^{*} q\right)$ memiliki beberapa arti yaitu memanggil (call), menyatakan (proclaim), membaca (read), ${ }^{57}$ memohon (invoke, appeal), memerintah (summon). ${ }^{58}$ Arti dasar kata qra ialah menarik perhatian orang lain dengan menggunakan suara yang dapat didengar oleh orang tersebut untuk membangun kontak atau komunikasi. ${ }^{59}$ Reaksi umum yang diberikan terhadap panggilan ini biasanya diekspresikan dengan $h n^{*} u^{*}\left(u^{*} n^{*} h\right)$ yaitu menjawab dan $u m^{\wedge} v^{*}\left(V^{*} m \wedge u\right)$ mendengar. Gagasan teologis yang menarik dari $q^{*} r^{*} a$ dalam Perjanjian Lama ialah posisi Yahweh sebagai subyek atau Sang pemanggil. Termasuk pada pembahasan ini di mana Yahweh memanggil Adam (Kej. 3:9).

Dalam kitab Yesaya, penggunaan kata $q^{*} r^{*} a$ dengan Yahweh sebagai subyeknya menggunakan beberapa obyek, yaitu bintangbintang (Yes. 40:26), keturunan manusia (41:4), Abraham (51:2), Israel (41:9; 42:1), Koresh (45:3), dll. Pemanggilan Yahweh biasanya untuk mengajak seseorang beribadah atau melayani-Nya. Contoh-contoh penggunaan ini banyak ditemukan dalam literatur nubuatan. Pemanggilan Yahweh tidak hanya sekedar mengajak/ menarik obyek yang dipanggil, melainkan lewat pemanggilan ini Dia hendak menyatakan bahwa Dia adalah Allah yang berdaulat atasnya, Dialah yang memilikinya. Oleh sebab itu Dia berhak untuk menggunakannya sesuai dengan kehendak-Nya dan pada umumnya selalu digunakan untuk pelayanan khusus. Menurut Louis Jonker, dalam konteks pemanggilan Yahweh ini mengindikasikan adanya hubungan yang dekat antara Yahweh dengan pribadi yang dipanggil. ${ }^{60}$

Berbeda dengan pernyataan Jonker di atas, pemanggilan Yahweh ini terjadi di tengah-tengah keretakan hubungan dengan manusia ciptaan-Nya. Kebersamaan dan komunikasi yang transparan telah

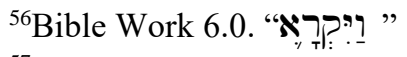

${ }^{57}$ Bible Work, 6.0

${ }^{58}$ Jonker, "ar*q," dalam New International Dictionary of Old Testament,

${ }^{59}$ Ibid.

${ }^{60}$ Jonker, " $\mathrm{r}^{*} \mathrm{q}$, ," dalam New International Dictionary of Old Testament,
} hlm. 3:971. hlm. 3:972. 
hilang, diwakili oleh persembunyian mereka di antara pepohonan. Di tengah-tengah upaya Adam untuk menjauhkan diri dari hadapan Allah, terjadilah pemanggilan Allah yang pertama kalinya. Menurut penulis, penggunaan kata memanggil mengandung dua gagasan penting yaitu pertama menunjukkan adanya kerinduan Allah untuk bersama kembali dengan Adam dan kedua adalah kebenaran terhadap Allah yang Maha tahu sehingga Ia tidak perlu mencari, walaupun Adam dan Hawa bersembunyi, tetapi tidak dikatakan bahwa Allah mencari, melainkan Allah memanggil.

Hal yang menarik dalam konteks pertanyaan TUHAN Allah yang pertama ini ialah mengapa Allah mengawali pertanyaan-Nya dengan bertanya "Di manakah engkau?" Bukankah sebaiknya Allah bertanya "mengapakah engkau bersembunyi?"

Penulis meyakini, bahwa bukan tanpa arti penting Allah mengawali pertanyaan-Nya dengan kata "Di manakah". Pertanyaan pertama yang dilontarkan TUHAN Allah ialah menyerang posisi/ keberadaan mereka. Mengapa Allah terlebih dahulu menanyakan keberadaan mereka? Menurut penulis pertanyaan pertama ini terkait dengan tindakan bersembunyi yang mereka lakukan. Menurut mereka, dengan persembunyian mereka akan mendapatkan ketenangan dan keamanan dari kesalahan yang telah mereka lakukan. Ini sejalan dengan tujuan dari pada seseorang yang berupaya menyembunyikan dirinya. Akan tetapi apa yang mereka lakukan tidak berdampak pada apa yang mereka harapkan. Tuhan Allah berfirman dengan nada

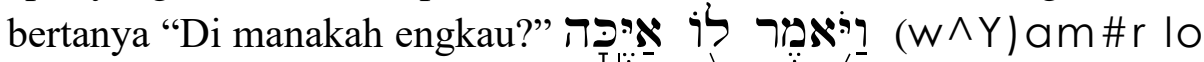

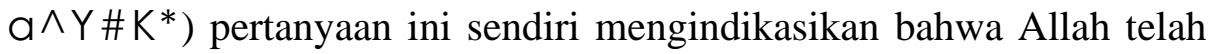
mengetahui bahwa mereka sedang bersembunyi. Hal ini sangat didukung dengan ketiadaan kata mencari. Dengan pertanyaan Allah ini, Ia ingin menyatakan kepada mereka bahwa bersembunyi bukanlah tindakan yang benar dalam konteks melakukan kesalahan. Betapa bodoh, lemah dan sia-sianya usaha mereka untuk bersembunyi dari hadapan Allah. ${ }^{61}$

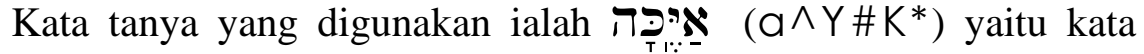
ganti tanya dari kata yа⿷ ( $а @ y)$ dengan parsing: orang kedua, maskulin, tunggal, terjemahannya ialah "di manakah engkau

${ }^{61}$ Victor P. Hamilton, The New International Commentary on the Old Testament: The Book of Genesis Chapters 1-17 (Grand Rapids: William B. Eerdmans Publishing, 1990), hlm. 193. 
(tunggal)?” Kata ya回 ( $a @ y)$ biasanya diterjemahkan "di mana," penambahan akhiran "kah" biasanya diikuti dengan enklitik hz\# (z\#h) sehingga diterjemahkan "di manakah."62 Penggunaan dalam bentuk idiom, biasanya dengan akhiran dan mendahului kata benda yang ditunjukkannya. Jika digunakan sendiri, atau dengan keterangan yang lain biasanya dengan ya回 ( $\mathrm{a} @ \mathrm{y})$. Bentuk yang paling umum dari kata ini ialah אַי.. (A^Y@h). ${ }^{63}$

Asal kata yа回 biasanya selalu dihubungkan dengan bahasa Ugaritik ay. Sebagian besar dari kata itu, sebanyak 30 kali digunakan dalam bentuk kalimat tanya retorik. ${ }^{64}$ Kata tanya keterangan ini terkadang digunakan dalam hal meminta informasi (Kej. 18:9; 22:7; 1 Sam. 9:18), tetapi dalam penggunaan ini sangat sering bukanlah jawaban yang diharapkan, inilah yang disebut dengan retorik. Bentuk seperti ini terutama sekali digunakan dalam bagian puisi. Di manakah gerangan kepanasan amarah orang penganiaya itu? (Yes. 51:13), bila orang binasa di manakah ia? (Ayb. 14:10).

Pada umumnya kata "dimana" digunakan oleh manusia ketika bertanya mengenai eksistensi dan kuasa Allah. Para musuh yang dinyatakan oleh Mikha bertanya kepadanya "Di manakah TUHAN Allahmu?" (Mi. 7:10), demikian juga dalam Mazmur 79: 10, bangsabangsa lain berkata "Di manakah Allah mereka (bangsa Israel)?", pertanyaan senada juga terdapat dalam Mazmur 115:2. Di tengahtengah kemerosotan moral dan dosa bangsanya yang menjadi pergumulan nabi Yeremia, mereka bertanya "Di manakah Firman TUHAN itu?" (Yer. 17:15), "Di manakah Allah yang menghukum?" (Mal. 2:17), Gideon juga pernah mempertanyakan penyertaan TUHAN, ketika mereka berada dalam cengkraman orang Midian, dan pada waktu itu Malaikat TUHAN datang kepadanya, dalam jawabannya Gideon bertanya"Di manakah segala perbuatan-perbuatan-Nya yang ajaib..."(Hak. 6:13).

\footnotetext{
${ }^{62}$ Reed, “yа, 回” dalam Bahan Kuliah: Kamus Sementara Bahasa IbraniIndonesia.

${ }^{63}$ Bible Work. “ya回”

${ }^{64}$ Herbert Wolf, “уа, 回” dalam Theological Wordbook of the Old Testament, peny., R. Laird Harris, Gleason L. Archer, Bruce K. Waltke (Chicago: Moody Press, 1980), hlm. 35.
} 
Kata ya回 pernah digunakan TUHAN dalam bentuk sarkasme ${ }^{65}$ kepada bangsa Yehuda. Ketika mereka murtad, membuat ilah-ilah kesia-siaan, menukarkan kemuliaan Allah dengan ilah lain, membelakangi Tuhan dan tidak menghadapkan wajah mereka kepada Tuhan, sehingga mereka ditimpa malapetaka dan pada waktu itu Tuhan bertanya "Di manakah para allahmu yang kau buat untuk dirimu?". Bentuk yang senada juga dikatakan TUHAN kepada bangsa Israel dalam nyanyian Musa, juga dalam konteks yang sama di mana bangsa Israel membangkitkan cemburu Allah dengan allah asing, mempersembahkan korban kepada roh-roh jahat, kepada allah yang tidak mereka kenal, sehingga Allah menimbun malapetaka atas mereka dan pada akhirnya kekuatan mereka sudah lenyap, maka Ia akan berfirman "Di manakah allah mereka,..."(U1. 32:16,17,23,36,37).

Dengan memahami beberapa penggunaan kata yа臣 serta konteks penggunaannya, dapat disimpulkan bahwa penggunaan kata y曰 penggunaan umumnya tidak dipakai untuk menanyakan tempat. Terlebih lagi ketika dalam konteks sebagai subyek (pelaku) adalah Allah. Pada umumnya untuk menanyakan tempat atau asal menggunakan kata $/ y ! a^{\wedge}\left(a^{\wedge} y ! /\right)$. Contoh penggunaannya ialah ketika Yakub bertanya kepada orang-orang yang disekelilingnya, "Saudarasaudaraku, dari manakah kamu ini?" (Kej. 29:4; Hak. 19:17). ${ }^{66}$ Oleh sebab itu, ketika TUHAN Allah bertanya kepada Adam dan Hawa, jelas bahwa Allah tidak mengajukan pertanyaan untuk mendapat informasi tentang keberadaan mereka. Pertanyaan Allah ini lebih dapat dipahami dalam bentuk pertanyaan retorik Allah. Yaitu bukan untuk mengetahui, tetapi untuk memberitahukan, membimbing, menuntun dan membangkitkan kesadaran si pelaku. ${ }^{67}$ Lebih jelasnya terdapat dalam defenisi berikut, yaitu sebuah pertanyaan yang tidak memerlukan jawaban, tetapi memaksa orang untuk menjawab dalam mentalnya dan memikirkan implikasi dan konsekuensinya. ${ }^{68}$ Contoh penggunaannya ialah dalam Mazmur 56:11-12, "Kepada Allah, firman-Nya kupuji,

\footnotetext{
${ }^{65}$ Sarkasme ialah penggunaan kata-kata pedas untuk menyakiti hati orang lain; cemoohan atau ejekan kasar. Seperti terdapat dalam Tim Penyusun, "Sarkasme" dalam Kamus Besar Bahasa Indonesia (Jakarta: Balai Pustaka, 2001), hlm. 1000.

${ }^{66}$ Wolf, “ув, ${ }^{0} ”$ dalam Theological Wordbook of the Old Testament, hlm. 35.

${ }^{67}$ Dalam diskusi bersama dengan Bpk. Ari Upu Telo. Yogyakarta, 09-02-07; 08.50-0915.

${ }^{68}$ Artikel perkuliahan: Prinsip-prinsip Khusus: Figures of Speech. Metode Mempelajari Alkitab Lanjutan (MMAL).
} 
kepada YAHWEH, firman-Nya kupuji... Apakah yang dapat dilakukan manusia terhadap aku?." Dalam hal ini ia memang ingin membangkitkan mentalnya dengan meyakini bahwa sesungguhnya manusia tidak dapat berbuat apapun kepadanya. Kebenaran ini yang diharapkan Allah ketika Ia mengajukan pertanyaan-Nya yakni agar Adam dan Hawa memikirkan implikasi dan konsekuensi dari perbuatan mereka. Namun sebaliknya, bukannya menyadari kesalahan mereka justru saling melemparkan kesalahan.

Permasalahan selanjutnya dalam pengamatan teks ialah pemanggilan dan pengalamatan pertanyaan yang digunakan dalam bentuk tunggal. Dari konteks terlihat bahwa pelakunya ialah jamak (dua orang). Bentuk tunggal yang digunakan dengan jelas mengarahkan pertanyaan hanya kepada Adam. Mengapakah pertanyaan ini ditujukan hanya kepada Adam? Bukankah mereka berdua yang bersembunyi? dan mereka berdua sama-sama telah berdosa, lebih lagi Hawa yang terlebih dahulu mengambil dan memakan buah itu? Bukankah sebaiknya pertanyaan ditujukan kepada Hawa atau setidaknya secara bersama-sama kepada mereka berdua? Terhadap kasus ini tidak banyak penafsir yang memberikan argumen. Berikut ini pendapat Zakaria mengenai pengalamatan pertanyaan kepada Adam.

Firman-Nya: "Siapakah yang memberitahukan kepadamu, bahwa engkau telanjang? Apakah engkau makan dari buah pohon yang kularang engkau makan itu?" (Kej. 3:11). Pertanyaan ini ditujukan kepada Adam, karena dialah yang dijadikanNya kuasaNya di bumi, dialah juga yang diberitahukan tentang pohon itu, kepadanya juga Allah telah memberikan hukum Allah mengenai pohon itu. Dialah kepala dari semua, kepala isterinya juga, kepadanya semua tunduk termasuk isterinya. Adam yang diinterogasi Allah, karena dialah kepala isteri, bertanggung jawab atas kesalahan isterinya; Ia berkewajiban menguduskannya dan menempatkannya di hadapannya sendiri dengan cemerlang tanpa cacat atau kerut atau yang serupa itu, supaya isterinya kudus dan tidak bercela (Ef. 5:23-28). ${ }^{69}$

Sedangkan Stanley Heath memandang kasus ini dari segi struktur wewenang yang ditetapkan Allah, yaitu kepada Adam. ${ }^{70}$ Dengan

${ }^{69}$ D. E. Zakaria, Adam Dimanakah Engkau? (Yogyakarta: ANDI, 1986), hlm. 54

${ }^{70} \mathrm{~W}$. Stanley Heath, Tafsir Kitab Kejadian Pasal 1-11: Relevansinya dengan Pemulihan Gereja di Akhir Zaman (Yogyakarta: ANDI, 1998), hlm. 58. 
sedikit berbeda dengan Zakaria, Victor P. Hamilton berpendapat bahwa "memang tidak dapat memastikan mengapa pertanyaan-pertanyaan TUHAN hanya ditujukan kepada pria itu, tetapi mungkin karena kelakuan atau tindakan perempuan itu digolongkan dengan pria itu"71 Dengan kata lain, yaitu diwakilkan. Sedangkan menurut Horatius Bonar, tidak menjadi masalah kepada siapa pertanyaan itu dialamatkan. ${ }^{72}$ Mengenai hal ini penulis sependapat dengan Zakaria, yakni bahwa Adam harus bertanggung jawab sebagai kepala atas isterinya.

\section{"Siapakah yang memberitahukan kepadamu, bahwa engkau telanjang?"

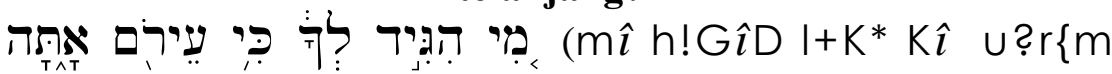$$
\left.a^{*} T^{*} h\right)
$$

Pertanyaan Allah terhadap Adam sungguh tidak dipahami olehnya. Adam memaknai pertanyaan itu secara literal dan kemudian menjawab sesuai dengan pemahamannya. Adam menjelaskan alasan mengapa ia bersembunyi, yaitu karena ia mendengar Allah ada dalam taman, kemudian ia takut, karena telanjang sehingga ia bersembunyi. Apakah Allah sungguh menginginkan jawaban Adam itu? Menurut penulis tidak, sebab Allah telah mengetahui itu semua, bahwa sebelum Adam mengucapkan sekalipun. Ketidakmengertian Adam terhadap arah dan maksud pertanyaan Allah merupakan salah satu dari konsekuensi dosa, yaitu tidak dapat meresponi Allah dengan benar. Jawaban Adam lebih bersifat dalih ${ }^{73}$ daripada menjawab langsung maksud pertanyaan Allah.

Dua hal yang menarik untuk dicermati dari jawaban Adam ialah pertama, ia takut karena mendengar Allah ada dalam taman; kedua, ia bersembunyi karena telanjang. Sebelum jatuh dalam dosa, kehadiran dan kebersamaan dengan Allah merupakan hal yang dinikmati oleh Adam. Ungkapan Adam "aku menjadi takut" merupakan dampak

${ }^{71}$ Victor P. Hamilton, "Genesis," dalam The New International Commentary on the Old Testament: The Book of Genesis Chapters 1-17 (Grand Rapids: William B. Eerdmans Publishing, 1990), hlm. 1:193.

${ }^{72}$ Horatius Bonar, Thoughts on Genesis (Grand Rapids: Kregel Publications, 1979), hlm. 140.

${ }^{73}$ Dalih adalah alasan yang dicari-cari untuk membenarkan suatu perbuatan, untuk menghindari tugas, dan untuk menutupi perbuatan yang salah atau tercela. 
psikologis dari perbuatan dosa yang ia lakukan. Rasa takut yang pertama lahir dalam diri manusia ialah dalam konteks ini yaitu terhadap kehadiran Allah.

Allah tidak membantah jawaban Adam, walaupun sesungguhnya Ia tidak puas dengan jawaban Adam itu. Selanjutnya melalui jawaban Adam, Allah mengajukan pertanyaan kedua "Siapakah yang memberitahukan kepadamu, bahwa engkau telanjang? Bentuk pertanyaan ini terkesan mengejar Adam atas apa yang baru saja dikatakannya. Dari pertanyaan kedua ini, penulis yakin bahwa Allah tidak menginginkan jawaban mengenai oknum siapa yang memberitahukan, dalam kepentingannya dengan Allah, Ia telah mengetahui. Oleh sebab itu pertanyaan ini walaupun ditanya kepada Adam, namun kepentingannya juga untuk Adam. Ketika Allah bertanya "siapa" Allah sebenarnya ingin mengingatkan Adam pada peristiwa memakan buah pohon yang dilarang oleh Allah, hal ini terbukti di mana pada pertanyaan selanjutnya Allah sendiri yang langsung menegaskannya. Dari jawaban yang pertama, Adam sama sekali tidak mengarah ke sana dan melangkah jauh dengan berdalih pada perasaan takut dan kondisi fisik telanjang.

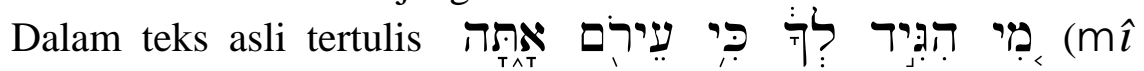
$\mathrm{h} ! \mathrm{G} \hat{\imath} \mathrm{D} \mid+\mathrm{K}^{*} \mathrm{~K} \hat{\imath} \cup ? \mathrm{r}\left\{\mathrm{m} \mathrm{a}^{*} \mathrm{~T}^{*} \mathrm{~h}\right)$. Kata tanya yang digunakan pada pertanyaan kedua ialah ym! $(\mathrm{m} \hat{\imath})$ artinya siapa. Kata ganti tanya ym! (siapa) tidak memiliki deklinasi, yaitu bentuknya tidak berubah dengan kasus, jenis, atau jumlah. ${ }^{74}$ Beberapa fungsi kata $m \hat{\imath}$ ialah sebagai kata tanya "Siapa?" (Kej. 3:11, bnd. Hak. 18:3), kata ganti yang tak tentu "barang siapa" (Kel. 32:36, bnd. Hak. 7:3), optatif "sekiranya" (II Sam. 15:4), dan adverbia "bagaimana" (Ams. 7:2,5). ${ }^{75}$ Dalam konteks ini, ym! berfungsi sebagai kata tanya.

Kata tanya ym!(mîl) biasanya selalu menunjuk pada orang (person) dan hanya mencari identitas (identity), keturunan (ancestry), atau beberapa fakta eksternal. Penggunaan kata ym! hubungannya dengan manusia sebanyak 36 kali. Beberapa contoh penggunaannya ialah ketika Ribka bertanya kepada Eliezer hamba Abraham "Siapakah lakilaki itu yang berjalan di padang ke arah kita?" (Kej. 24:65), demikian juga pertanyaan Firaun kepada Musa dan Harun, pada peristiwa

\footnotetext{
${ }^{74}$ Reed dan Sedi, Diktat Kuliah.

${ }^{75}$ Ibid.
} 
pembebasan bangsa Israel dari perbudakan Mesir ketika TUHAN Allah mendatangkan tulah kedelapan: Belalang, ia bertanya "Siapa-siapa sebenarnya yang akan pergi itu?" (Kel. 10:8). Dengan demikian jelas bahwa kata ym! digunakan untuk menanyakan seseorang, baik yang telah, sedang maupun yang akan melakukan sesuatu. Akan tetapi ada beberapa orang yang berpendapat bahwa kata ym! pada Kejadian 3:11; 33:8 dan 2 Tawarikh 2:6 adalah pengecualiaan dari penggunaan umumnya, kata ini lebih bersifat pengumuman atau pemberitahuan. ${ }^{76}$ Khusus Kejadian 3:11 yang merupakan pembahasan pada bagian ini, penulis memiliki pandangan yang berbeda dengan pendapat yang terakhir, karena konteksnya adalah bentuk dialog atau tanya jawab Adam dengan TUHAN Allah.

Dengan pertanyaan siapa, Allah ingin memberitahukan Adam otoritas Allah atas segalanya, ${ }^{77}$ dan bukan pada ular maupun iblis yang menggoda Hawa. Sasaran pertanyaan Allah yang kedua ini untuk menyatakan kepada Adam dampak dari perbuatannya dan terus menyadarkan dia dari perbuatannya.

"Apakah Engkau Makan dari Buah Pohon, yang Kularang Engkau Makan itu?"

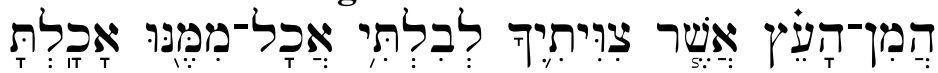
$\left(H \& m ! n^{-} H^{*} U @ x A \& v \# r x ! R \hat{\imath} H^{*} \mid=b ! I T \hat{\imath} A \& K^{*} I^{-}<! M \# N W\right.$ $A^{*} K^{*} I=T^{*}$ )

Pertanyaan ketiga ini merupakan pertanyaan yang nadanya sama dengan pertanyaan kedua, yaitu berbentuk penegasan. Kedua pertanyaan penegasan ini lahir oleh karena pernyataan Adam yang mengatakan bahwa alasan dia bersembunyi adalah ketelanjangannya (bandingkan kondisi mereka sebelum memakan buah terlarang, yakni tetap telanjang tetapi tidak bersembunyi dari hadapan Allah). Tentu Allah memahami bahwa ini hanya merupakan dalih semata.

Fokus Allah pada pertanyaan ketiga ini semakin terlihat jelas ketika Ia menyebutkan kata "buah pohon." Allah memancing Adam dan menyegarkan ingatannya akan perintah yang telah diberikan-Nya

\footnotetext{
${ }^{76}$ Walter C. Kaiser, “ym,!” dalam Theological Wordbook of the Old Testament, hlm. 503

${ }^{77}$ Biblical Study Library. file:///E:/DOCS/0001F/01F55.HTM\#TopOfPage. Lesson 4: The Fall of Man (Genesis 3:1-24). [CD ROOM]
} 
mengenai buah pohon terlarang itu. Rangkaian pertanyaan Allah ini tidak dapat dipahami secara sederhana, penulis yakin sistematika pertanyaan ini juga mengandung makna yang mendalam. Tentu pertanyaan Allah yang ketiga ini diajukan, karena Adam sungguh belum memahami makna pertanyaan Allah sebelumnya. Adalah sulit untuk menerima kebenaran yang mengatakan bahwa Allah sungguh ingin mengetahui keberadaan dan penyebab kondisi mereka demikian. Allah tidak sedang meyakinkan diri-Nya melalui jawaban yang hendak diberikan Adam. Mencari pengetahuan akan suatu hal adalah salah satu pekerjaan yang tidak akan pernah dikerjakan Allah, sebab Dia adalah Allah yang Mahatahu. A. W. Tozer mendiskripsikan pengetahuan Allah demikian:

Allah mengetahui dengan segera dan tanpa perlu berusaha mengenai semua dan segala hal, segala dan setiap pikiran, semua roh dan segala macam roh, segala makhluk dan setiap makhluk, segala sesuatu semuanya, segala dan setiap hukum, segala macam hubungan, segala macam sebab, segala macam gagasan, segala macam misteri, segala macam pelik, segala macam perasaan, segala macam keinginan, setiap rahasia yang tidak diucapkan, segala takhta dan kerajaan, segala pribadi, segala hal yang dapat dilihat dan yang tidak dapat dilihat di sorga dan di bumi, gerakan, ruang, waktu, kehidupan, kematian, kebaikan, kejahatan, sorga dan neraka. ${ }^{78}$

Dengan demikian adalah jelas bahwa pertanyaan ini, kendati bernada penegasan, namun bukan untuk meyakinkan diri Allah akan apa yang telah dilakukan oleh Adam dan Hawa.

Pertanyaan ketiga yang diajukan Allah dengan menggunakan kata Tanya "apakah?.” Pertanyaan "apakah?" dalam bahasa Ibrani memakai satu awalah khusus 끄 (h\&) sebagai awalan Tanya (seperti akhiran “kah” dalam bahasa Indonesia). ${ }^{79}$ Dalam terjemahan bahasa Inggris, pertanyaan ini lebih sering diterjemahkan dalam bentuk kalimat tanya perfect tense. Akan tetapi terdapat juga beberapa versi Alkitab dalam bahasa Inggris yang tidak menggunakan awalan tanya, seperti menggunakan kata "whereof, unless."

${ }^{78}$ A. W. Tozer, Mengenal Yang Mahakudus, pen., Pauline Tiendas-Iskandar (Bandung: Yayasan Kalam Hidup, 1995), hlm. 81.

${ }^{79}$ Reed dan Sedi, Diktat Kuliah. 
Partikel interrogative 그 (h\&) adalah awalan dari sebuah kalimat atau klausa, kebanyakan digunakan dalam pertanyaan langsung. Penggunaannya tergantung pada konsonan pertama dan vocal kata yang diikuti oleh partikel ini. Biasanya pertanyaan sederhana dalam bahasa Ibrani memakai interrogative הָ. Terkadang partikel ini tidak ditemukan dalam kalimat, namun bentuk kalimat tanyanya kelihatan jelas. Contoh, "Akankah Saul memerintah atas kita?" (1 Sam. 11:12 dalam King James Version). Dalam bentuk ini tidak terdapat indikator interrogativenya. Ketika הె digunakan dalam pertanyaan, pertanyaan itu sesungguhnya tidak sedang meminta informasi tetapi lebih kepada pertanyaan retoris yang biasanya mengharapkan jawaban negatif (“Apakah aku penjaga adikku" (Kej. 4:9) dan terkadang jawaban positif. $^{80}$

Penggunaan הָ akan terlihat lebih jelas dalam literatur nabi-nabi, salah satunya seperti dalam kitab Yeremia. Dalam beberapa hal, partikel ini digunakan paralel dengan A!m. Dalam Yeremia 18:14 terdapat dua bentuk pertanyaan yang menggunakan $h \&$ dan $A ! m$. Kedua pertanyaan ini jelas membutuhkan jawaban negatif. Namun Yeremia melanjutkan pada ayat 15 dengan mengatakan bahwa umat Allah telah melupakan-Nya. Jadi, kedua pertanyaan retorikal itu digunakan untuk mengintensipkan betapa hebatnya kemarahan Allah pada perpecahan yang tidak wajar antara diri-Nya dan umat-Nya. Yeremia mungkin menggunakan dua pertanyaan retorikal untuk mengatakan dengan cara lain prasuposisi umum yang dapat diterima dan kemudian menantangnya $(2: 14,31 ; 3: 5 ; 8: 4)$ atau untuk mengekspresikan dogma keyakinan tradisional $(8: 19,22 ; 14: 19,22) .{ }^{81}$

Awalan tanya I ( $\& \&$ ) dapat digunakan baik dalam kalimat tanya langsung maupun tidak langsung. Beberapa fungsinya dalam kalimat langsung ialah pertama digunakan dalam kalimat tanya sederhana, di mana jawaban yang diharapkan tidak pasti, kedua, sering digunakan dalam pertanyaan-pertanyaan yang bernada mengejutkan (surprise), maupun yang berbentuk retorikal, untuk pertanyaan yang mengharapkan jawaban negative. Terkadang dalam penggunaannya

\footnotetext{
${ }^{80}$ Hamilton, "ה,," dalam Theological Wordbook of the Old Testament, hlm. 204.

${ }^{81}$ Brueggemann, W.M, Jeremiah's Use of Rhetorical Questions, “JBL 92: 35874. Dalam Theological Wordbook of the Old Testament, hlm. 204.
} 
satu atau lebih kata mendahului הㄱ (h\&) (dalam klausa yang sama) untuk penekanan khusus, ketiga, digunakan dalam pertanyaanpertanyaan yang kelihatannya meragukan sesuatu yang tidak dapat disangkal, keempat, dalam pertanyaan-pertanyaan disjungtif, ${ }^{82}$ bentuk yang pertama biasanya diperkenalkan melalui 그 (h\&), kedua melalui אִ $(A ! m)$ atau (yang lebih jarang digunakan) $(W=A ! m) .{ }^{83}$ Dari beberapa penggunaan awalan tanya ㄱ.? (h\&) dalam konteks ini berfungsi menyatakan pertanyaan dalam bentuk retoris. Model pertanyaan ini dapat dinilai dalam bentuk retoris dilatar belakangi oleh penggunaan kata, konteks dan nilai-nilai teologis dari sifat-sifat Allah.

\section{"Apakah yang Telah Kau Perbuat ini?"

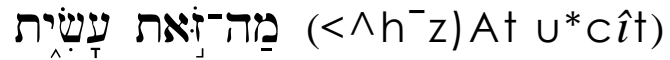

Berbeda dengan ketiga pertanyaan sebelumnya, pertanyaan yang terakhir ini ditujukan Allah kepada Hawa. Pertanyaan ini lahir di tengah-tengah puncak tertinggi kesalahan Adam setelah jatuh dalam dosa. Diawali dengan ketidakjujurannya yang mengalaskan ketelanjangan sebagai alasan persembunyiannya (Kej. 3:10), hingga akhirnya menyalahkan perempuan yang diciptakan Allah, bahkan lebih lagi, ketika ia berkata "Perempuan yang Kau tempatkan di sisiku, dialah yang memberi dari buah pohon itu kepadaku, maka kumakan" sebenarnya ia sedang menyalahkan Allah yang menciptakan dan menempatkannya bersama dengan Adam (bndk. Kej. 2:23). Jawaban inilah yang membuat Allah menutup pertanyaan dengan Adam dan memulai dengan Hawa berdasarkan referensi Adam.

Tidak jauh berbeda dengan Adam suaminya, Hawa juga melemparkan kesalahan kepada ular. Sehingga jelas kesamaan karakter mereka setelah jatuh dalam dosa. Bentuk pertanyaan Allah yang terakhir ini ialah dengan menggunakan kata ganti tanya $\mathrm{hm}^{*}\left(\mathrm{~m}^{*} \mathrm{~h}\right)$. Kata ganti tanya $m^{*} h$ digunakan lebih signifikan ketika dihubungkan dengan kata "nama." Adapun fungsi kata ganti tanya hm* $\left(m^{*} h\right)$ ialah pertama, sebagai kata tanya, “Apa?” (Kej. 4:10), kedua, sebagai kata

\footnotetext{
${ }^{82}$ Pertanyaan disjungtif dapat mengekspresikan sebuah alternative yang nyata (kecuali dalam puisi), pemikiran-pemikiran yang sama dapat diulangi dalam bentuk yang berbeda, dalam dua klausa paralel.

${ }^{83}$ Bible Work 6. WTM Morphology + Whittaker`s Revised BDB Lexicon entry $(781,780,206)$.
} 
ganti yang tidak tentu, "apapun," penggunaan dalam konteks ini lebih jarang (Bil. 23:3), ketiga, Adverbia, diterjemahkan dalam dua arti, "Bagaimana?" (2 Raj. 4:43) dan "Mengapa?" (2 Raj. 6:33), keempat, sebagai kata seru, "Alangkah!" (Kej. 28:17), dan kelima, berfungsi menyatakan arti negatif, suatu pemakaian yang jarang ditemukan, yang timbul dari pemakaian $\mathrm{hm}^{*}\left(\mathrm{~m}^{*} \mathrm{~h}\right)$ dalam pertanyaan retoris. ${ }^{84}$

Dalam konteks ini kata ganti tanya $m^{*} h$ berfungsi sebagai kata tanya yang lebih mengacu pada perbuatan yang telah dilakukan. Allah bertanya dan juga mengandung unsur pertanggungjawaban atas apa yang diperbuat Hawa. Tetapi Allah tidak mendapatkan yang diinginkan-Nya, sementara Hawa dengan lantangnya melemparkan kesalahan pada ular. Dan dalam konteks ini kembali penulis menegaskan bahwa pertanyaan Allah ini tidak untuk mendapatkan informasi mengenai peristiwa yang telah terjadi, namun membuka diri untuk menerima informasi dari Adam dan Hawa yang setidaknya bernada pengakuan.

\section{E. KESIMPULAN}

Setelah melakukan pembahasan studi teks Kejadian 3:8-13, yang secara khusus memberikan konsentrasi pada kalimat tanya yang digunakan, maka penulis menyimpulkan bahwa keempat rangkaian pertanyaan Allah jelas bersifat retorikal seperti yang telah dijelaskan di atas. Kebenaran gaya bahasa retorikal dalam gaya bahasa pertanyaan Allah telah terbukti dengan jelas, ditambah dengan gagasan teologis mengenai hakekat Allah. Pertanyaan-pertanyaan retoris Allah ini bukanlah demi kepentingan Allah, sebaliknya demi manusia itu sendiri. Allah tidak harus bertanggung jawab terhadap apa yang telah terjadi, dengan demikian Dia tidak harus datang (dari segi tanggung jawab). Kasih Allah kepada Adam dan Hawa inilah yang menjadi motif dasar kedatangan Allah.

Dengan mempelajari teks dan gaya bahasa yang digunakan Allah, penulis melihat bahwa sesungguhnya Allah telah mengetahui dengan jelas keberadaan Adam (jasmani dan rohani). Kendati tertuang dalam bahasa pertanyaan yang bernada mencari informasi dan meminta kepastian, namun itu semua hanya pendekatan bahasa yang dilakukan

${ }^{84}$ Reed dan Sedi, Diktat Kuliah. 
kepada Adam untuk membangkitkan kesadarannya dan membawa dia pada suatu pengakuan. Gaya bahasa seperti ini (seolah-olah ingin tahu) memang juga bentuk penyajian gaya bahasa retorik. Pilihan kata yang disajikan oleh penulis kitab Kejadian, dan pembentangan Allah sebagai pencipta dan penguasa sangat mendukung kebenaran gaya bahasa retorikal Allah ini.

Merupakan tujuan penulisan bab ini untuk menunjukkan bahwa konteks Allah bertanya kepada Adam dan Hawa jelas tidak berkaitan dengan informasi. Adam dalam kapasitasnya sebagai manusia yang telah berdosa mencoba menjawab setiap pertanyaan Allah, namun tidak satupun jawaban itu yang menyenangkan hati Allah. Jawaban Adam lebih terkesan sebagai upaya untuk melepaskan tanggung jawab atas apa yang telah diperbuatnya.

\section{DAFTAR PUSTAKA}

Alkitab. Jakarta: Lembaga Alkitab Indonesia, 2010.

Aalders, G. Ch. "Genesis." Dalam Bible Student's Commentary. Diterjemahkan oleh William Heynen. Grand Rapids: Zondervan Publishing House, 1981.

Aitken, K. T. "um^v*." Dalam New International Dictionary of Old Testament Theology. Disunting oleh Willem A. VanGemeren (Carliste: Paternoster Press, 1997.

Archer dan Lainnya, "Voice." Dalam Vine's Complete Expository Dictionary of Old and New Testament Words, Disunting oleh W. E. Vine, Merrill F. Unger \& William White. Nashville: Thomas Nelson Publisher, 1798.

Artikel Perkuliahan: Prinsip-prinsip Khusus: Figures of Speech. Metode Mempelajari Alkitab Lanjutan (MMAL).

Bible Work for Windows Copyright (C) 2003 Bible Works, LLC Version 6.0.005y WTM Morphology + Whittaker`s Revised BDB Lexicon entry (pg.1033,251). [CD ROOM] 
Biblical Study Library. file://E:/DOCS/0001F/01F55.HTM\# TopOfPage. Lesson 4: The Fall of Man (Genesis 3:1-24). [CD ROOM]

Bonar, Horatius. Thoughts on Genesis. Grand Rapids: Kregel Publications, 1979.

Brueggemann, W.M, Jeremiah's Use of Rhetorical Questions, "JBL 92: 358-74. Dalam Theological Wordbook of the Old Testament.

Budi, Samgar Setia Diktat Kuliah: Bahasa Ibrani. Semester V, 2003.

Davis, John J. Eksposisi Kitab Kejadian "Suatu Telaah dalam Kitab Kejadian. Malang: Gandum Mas, 2001.

Hamilton, Victor P. "Genesis." Dalam The New International Commentary on the Old Testament: The Book of Genesis Chapters 1-17. Grand Rapids: William B. Eerdmans Publishing, 1990.

Heath, W. Stanley. Tafsir Kitab Kejadian Pasal 1-11: Relevansinya dengan Pemulihan Gereja di Akhir Zaman. Yogyakarta: ANDI, 1998.

Hill, Andrew E. "ab*j."*" Dalam New International Dictionary of Old Testament Theology. Disunting oleh Willem A. VanGemeren. Carliste: Paternoster Press, 1997.

Jonker, Louis “аг"ч." Dalam New International Dictionary of Old Testament Theology. Disunting oleh Willem A. VanGemeren. Carliste: Paternoster Press, 1997.

Kaiser, Walter C. "ym!." Dalam Theological Wordbook of the Old Testament Theology. Disunting oleh Willem A. VanGemeren. Carliste: Paternoster Press, 1997.

Leupold, H. C. Exposition of Genesis. Grand Rapids: Baker Book House, 1982.

LXX Septuaginta Rahlfs’ (LXT) dan Modern Greek Bible (MGK).

Merrill, Eugene H. "el^h." Dalam New International Dictionary of Old Testament Theology and Exegesis. Disunting oleh Willem A. VanGemeren. Carliste: Paternoster Press, 1997.

Meyers, Rick. Strong 's Hebrew and Greek Dictionaries. e-Sword-the Sword of the LORD with an electronic edge, 2004. [CD-ROOM]. 
Munthe, Eben. 'Implikasi Penggunaan 'El' Dan 'YHWH' Dalam Kekristenan Masa Kini." KURIOS (Jurnal Teologi dan Pendidikan Agama Kristen) 5, no. 1 (2019): 54-73.

Owens, John Joseph. Analytical Key to the Old Testament, Jilid. 1. Genesis-Joshua. Grand Rapids: Baker Book House, 1995.

Reed, Carl dan Johny Y. Sedi, Diktat Kuliah: Bahasa Ibrani Jilid III Grammar dan Sintaks. Bahan Kuliah Semester V: 2004.

Sailhamer, John H. "Genesis." Dalam The Expository Bible Commentary, Disunting oleh Frank E. Gaebelein. Grand Rapids: Zondervan Publishing House, 1991.

Siahaya, Karel Martinus. "Dampak Sosial Politik Terhadap Perkembangan Ekonomi Umat Allah Zaman Perjanjian Lama." Jurnal Teruna Bhakti 2, no. 1 (2019): 12-26.

Smith, R. Payne. "Genesis." Dalam Ellicott's Commentary on the Whole Bible, Disunting oleh Charles John Ellicott. Grand Rapids: Zondervan Publishing House. 1: Genesis-Numbers.

Tatulus, Fekky D Y. "Mengajarkan Konsep Trinitas Sebagai Pembekalan Apologetis Jemaat Di Era Disruptif." MAGNUM OPUS: Jurnal Teologi dan Kepemimpinan Kristenurnal Teologo dan Kepemimpinan Kristen 1, no. 1 (2019): 1-12.

Thiessen, Henry C. Teologi Sistematika. Direvisi oleh Vernon D. Doerksen. Malang: Gandum Mas, 2000.

Toussaint, Stanley D. Metode Studi Kata dalam Perjanjian Baru, Diterjemahkan oleh Ari Upu Telo. Bahan Kuliah Metode Mempelajari Alkitab Lanjutan Semester 3: 2004.

Tozer, A. W. Mengenal Yang Mahakudus, Diterjemahkan oleh Pauline Tiendas-Iskandar. Bandung: Yayasan Kalam Hidup, 1995.

Untoro, Tri. “Trinitas Dalam Konsep Sang Logos Bersama Sang Theos Menurut Yohanes 1: 1." MAGNUM OPUS: Jurnal Teologi dan Kepemimpinan Kristen 1, no. 1 (2019): 22-29.

Wagner, Siegried dan Leipzig, "ab*j.” Dalam Theological Dictionary of the Old Testament, Disunting oleh G. Johanes. Botterweck dan Helmer Ringgren, Diterjemahkan oleh David E. Green. Grand Rapids: William B. Eerdmans Publishing, 1978. 
Wenham, Gordon J. Word Biblical Commentary Genesis 1-15. Disunting oleh John D. W. Watts. Waco: Word Books Publisher, 1987.

Wiryadinata, Halim. "An Analysis of Economic Wealth of God's People from Nomadic to Post Exilic Era." DUNAMIS: Jurnal Teologi dan Pendidikan Kristiani 3, no. 2 (2019): 155.

Wolf, Herbert. "ya回." Dalam Theological Wordbook of the Old Testament, Disunting oleh R. Laird Harris, Gleason L. Archer, Bruce K. Waltke. Chicago: Moody Press, 1980.

Zakaria, D. E. Adam Dimanakah Engkau? Yogyakarta: ANDI, 1986. 